\title{
Robbing Peter to Pay Paul: Public Assistance, Monetary Sanctions, and Financial Double-Dealing in America
}

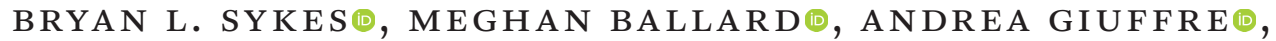 \\ REBECCA GOODSELL, DANIELA KAISER, VICENTE CELESTINO \\ MATA๑, AND JUSTIN SOLA
}

Research on punishment and inequality finds that people with criminal records routinely avoid systems of surveillance. Yet scholarship on monetary sanctions shows that many people experiencing poverty with criminal legal system debt are also involved with the state in other domains of social life. How can these literatures be resolved? In this article, we posit that past research can be reconciled through a focus on financial double-dealing-disparate and contradictory economic entanglements that redistribute welfare resources from individuals to the criminal legal system and its institutional affiliates. Drawing on nationally representative survey data, as well as unique data collected on people with monetary sanctions in seven states, we find that individuals and families receiving cash and noncash public assistance are significantly more likely to owe monetary sanctions and are less likely to pay them. We discuss the implications of multiple-system involvement for ongoing surveillance.

Keywords: financial double-dealing, monetary sanctions, welfare, punishment, public assistance

Bryan L. Sykes is a Chancellor's Fellow, an Inclusive Excellence Term Chair Professor, and an associate professor of Criminology, Law and Society (and by courtesy, Sociology \& Public Health) at the University of California, Irvine, United States. Meghan Ballard is a doctoral student in the Department of Criminology, Law and Society at the University of California, Irvine, United States. Andrea Giuffre is a doctoral candidate in the Department of Criminology and Criminal Justice at the University of Missouri-St. Louis, United States. Rebecca Goodsell is a doctoral candidate in the Department of Sociology at the University of California, Irvine, United States. Daniela Kaiser is a doctoral student in the Department of Criminology, Law and Society at the University of California, Irvine. Vicente Celestino Mata is a doctoral student in the Department of Criminology, Law and Society at the University of California, Irvine, United States. Justin Sola is a doctoral candidate in the Department of Criminology, Law and Society at the University of California, Irvine, United States.

(c) 2022 Russell Sage Foundation. Sykes, Bryan L., Meghan Ballard, Andrea Giuffre, Rebecca Goodsell, Daniela Kaiser, Vicente Celestino Mata, and Justin Sola. 2022. "Robbing Peter to Pay Paul: Public Assistance, Monetary Sanctions, and Financial Double-Dealing in America." RSF: The Russell Sage Foundation Journal of the Social Sciences 8(1): 148-78. DOI: 10.7758/RSF.2022.8.1.07. This research was funded by a grant to the University of Washington from Arnold Ventures (Alexes Harris, PI). We thank the faculty and graduate student collaborators of the Multi-State Study of Monetary Sanctions for their intellectual contributions to the project. Partial support for this research came from a Eunice Kennedy Shriver National Institute of Child Health and Human Development research infrastructure grant, P2C HD042828, to the Center for Studies in Demography and Ecology at the University of Washington. This research was also supported by research funds from the Council on Research, Computing and Libraries at the University of California-Irvine. Direct correspondence to: Bryan L. Sykes, at blsykes@uci.edu, Department of Criminology, Law and Society, University of California, Irvine, 3317 Social Ecology II, Irvine, California 92697, 949-824-9583, United States.

Open Access Policy: RSF: The Russell Sage Foundation Journal of the Social Sciences is an open access journal. This article is published under a Creative Commons Attribution-NonCommercial-NoDerivs 3.0 Unported License. 
The United States is one of the richest nations in the world. Yet, poverty affects more than 10 percent of households and nearly 15 percent of all minor children across the country (Fox, Glassman, and Pacas 2020; Semega et al. 2020). Nearly 30 percent of children with unemployed parents of working age live in deep poverty, that is, households with incomes below 50 percent of the poverty line (Fox et al. 2015), and nearly one in four children in deep poverty will experience eviction by the age of fifteen (Lundberg and Donnelly 2019). Public assistance, however, helps mitigate the effects of poverty, reaching more than 20 percent of the U.S. population (Census Bureau 2015), with state and local governments spending approximately $\$ 673$ billion on public assistance programs in 2017 (Urban Institute 2020).

The emergence of public assistance programs in the United States dates back to the Great Depression, when the national unemployment rate peaked at 25 percent in 1934 and real wages sharply declined by as much as 60 percent (Margo 1993; Pimpare 2014; Rauschway 2008). Poverty rates soared during the 1930s, vacillating between 40 and 60 percent (Rauschway 2008; Pimpare 2014; Smolensky and Plotnick 1993). The election of Franklin D. Roosevelt to the presidency ushered in the New Deal, a series of public works projects, financial reforms, regulations, and social welfare programs aimed at getting people back to work and reducing the poverty rate (Rauschway 2008; Pimpare 2014). Although a number of social welfare programs did emerge from the New Deal, the Social Security Act of 1935 provided for unemployment insurance, old age pensions, and poor relief for the elderly, disabled, and minors (Rauschway 2008; Pimpare 2014). Since then, public assistance, as we know it today, has been reimagined and reformed, beginning with President Lyndon Johnson's 1964 declaration of the War on Poverty, and again in the mid- to late 1990s under President Bill Clinton's Personal Responsibility and Work Opportunity Reconciliation Act of 1996 (Simon 2007; Gustafson 2012; Hinton 2016).

Changes to public assistance programs during the late twentieth century occurred during a unique historical moment when the criminal legal system broadly expanded and dispropor- tionately concentrated punishment in America. Although poverty is ubiquitous, the convergence of poverty and punishment sets the United States apart from many Western nations (Simon 2007; Hinton 2016; Harris, Evans, and Beckett 2010). Growth in mass incarceration since the 1970s (Western and Wildeman 2009; Pettit 2012; National Research Council 2014), coupled with an increase in intergenerational economic immobility (Chetty et al. 2014), has placed many Americans and their children at an elevated risk of material hardship and severe deprivation (Schwartz-Soicher, Geller, and Garfinkel 2011; Sugie 2012; Sykes and Pettit 2015). Children with a formerly or currently incarcerated parent, for instance, experience severe socioeconomic consequences that amount to generational social exclusion (Foster and Hagan 2007), necessitating increased social safety net support (Hagan, Foster, and Murphy 2020).

Despite burgeoning research on the relationship between the criminal legal system and public assistance, little work has focused on how the receipt of public assistance affects the imposition and payment of monetary sanctions. Although judges often use receipt of public assistance as an indicator of financial indigence (Harris, Evans, and Beckett 2010; Harris 2016), it is unclear whether such assessments lead to reduced or waived monetary sanctions for individuals or families receiving public assistance. The Multi-State Study of Monetary Sanctions (MSSMS) dataset (see Harris, Pattillo, and Sykes 2022) offers a unique opportunity to theorize and analyze the relationship between public assistance and monetary sanctions (Harris 2016; Martin et al. 2018), particularly for families living at the margin.

In this article, we analyze two separate data sources to investigate both the general and nuanced relationship between public assistance and monetary sanctions. We find that individuals and families receiving public assistance are significantly less likely to pay their monetary sanctions than people not receiving public assistance, despite being significantly less likely to have the same amount of monetary sanctions imposed at sentencing. This research speaks to how the state engages in what we term financial double-dealing (FDD)-disparate 
and contradictory economic entanglements that redistribute welfare resources from individuals to the criminal legal system and its institutional affiliates. This FDD is important because fiscal allocations for criminal justice operations are currently being backfilled with resources allocated to people receiving public assistance who are also ensnared in the sprawling web of the criminal legal system. Our findings have implications for social policies aimed at limiting poverty and inequality and preventing FDD by the state in the imposition and collection of monetary sanctions for people on public assistance.

\section{RESEARCH ON MONETARY SANCTIONS}

Labor extraction, convict leasing, monetary sanctions, and debtors' prisons are examples of historical punishment practices that shape contemporary U.S. penal laws and sentences (Adamson 1983; Blackmon 2009; Wood and Trivedi 2007; Alexander 2010; Harris 2016). Today, monetary sanctions commonly accompany or replace formal imprisonment and function as a key mechanism of social control and surveillance of low-income communities and communities of color (Harris, Evans, and Beckett 2010; Kohler-Hausmann 2018).

The use of monetary sanctions varies considerably by jurisdiction because fines and fees are assessed based on unique guidelines established by local, state, and federal authorities (Bannon, Nagrecha, and Diller 2010; Gordon and Glaser 1991; Martin et al. 2018; O'Malley 2009; Ruback, Shaffer, and Logue 2004). Proponents of monetary sanctions claim that they promote a sense of accountability among justice impacted people, and that fines and fees are a socially efficient replacement for incarceration (Becker 1968; Becker 1976; for a review, see also Martin 2020). However, courts that impose fines and fees often fail to provide defendants the full extent of these sanctions at sentencing (Anderson 2008; Beckett and Harris 2011; Harris 2016; Martin et al. 2018). Some costs are not readily apparent, such as those related to public defenders (Colgan 2014), incarceration stays (Fernandes, Friedman, and Kirk 2022, this volume) and penalties for late payment (Harris 2016; Martin et al. 2018; Friedman et al. 2022, this volume). Even when peo- ple consistently make the minimum payments, the interest accrued on the principal debt can be crippling (Harris, Evans, and Beckett 2010). Furthermore, people under correctional supervision often have to agree to pay all legal financial obligations (LFOs) as a condition of release (Huebner and Shannon 2022, this volume).

The consequences of entwining money with punishment are numerous and well known. Monetary sanctions can affect nearly every facet of an individual's economic, political, and social life (see Harris, Pattillo, and Sykes 2022, this volume). They thus often further marginalize those who are in precarious financial positions (Bing, Pettit, and Slavinski 2022, this volume; Harris 2016). Moreover, in some locales, until LFOs are paid in full, individuals' criminal records cannot be cleared or expunged, and they may be sentenced to incarceration or community service or have their driver license suspended if they are unable to make payments (Harris 2016; Martin et al. 2018). These punishments for nonpayment may prevent individuals from finding or maintaining employment. In addition to documented racial discrimination in the job market (Bayot 2004; Pager 2003; Pager, Bonikowski, and Western 2009), civil judgments from monetary sanctions can damage one's credit and is often listed on credit reports that some employers use as part of the background check process (Harris, Evans, and Beckett 2010). Thus monetary sanctions may place people and their families at increased risk of poverty if individuals are unable to secure employment.

\section{THEORETICAL FRAMEWORK}

Loïc Wacquant (2010) contends that increasing American insecurity is the result of changing state priorities in local and national spending. on social welfare and punishment (see also Beckett and Western 2001). Simply put, he argues that the neoliberal push during the late twentieth century led to major structural changes in American life at the local, state, and national level, precipitating a spending shift from the "left hand" of the state (attending to issues of social welfare and public health) to the "right hand" (attending to matters of punishment and penality, national defense, and 
control over markets and the economy) (Wacquant 2010). As a result, the right hand of the state has disproportionately increased in power since the late twentieth century, and its penal arm has expanded to consume a greater proportion of public spending while also directly exacting social controls, incarceration, and violence against marginalized populations (Wacquant 2010). ${ }^{1} \mathrm{~A}$ consequence of this expansion of power and resources is that social service systems have increasingly been underfunded, or in some cases, entirely defunded, as the criminal legal system expanded (Ingraham 2020; Saez and Zucman 2019; see Beckett and Western 2001).

The downsizing of public assistance programs and the expansion of the criminal legal system aligns with research on the neoliberalization of punishment in the United States. This scholarship explores how the negative externalities associated with economic and political changes shift ownership of social problems from the government to individuals, propagating "the neoliberal trope of personal responsibility" (Friedman and Pattillo 2019, 174). Neoliberal "responsibilization" in the criminal legal system is not merely ideological. Recent scholarship shows how local, state, and federal policies apply these logics to ensnare (Muñiz 2020), imprison (Simon 2007; Hinton 2016; Wacquant 2009), and apply monetary sanctions to individuals as revenue generation and extraction tools that ostensibly act as coercive financialization and predation of the poor (Fernandes et al. 2019; Kirk, Fernandes, and Friedman 2020; Fernandes, Friedman, and Kirk 2022, this volume; Pattillo and Kirk 2021; Friedman and Pattillo 2019; Page, Piehowski, and Soss 2019).

Although recent research on neoliberalism and monetary sanctions underscore the pervasiveness of state control in imposing monetary sanctions, supporting the underlying theoretical argument of Loïc Wacquant (2009), this conceptual framework is limited. Wacquant's framing does not adequately theorize the integrated effects of monetary sanctions and welfare support on individuals, families, and communities because the macro approach to shifts in funding obscures the ways in which micro-level dispersions of public aid can recirculate into the penal arm of the state via the imposition of monetary sanctions.

We argue that, in the case of punishment and welfare, an economic sleight of hand emerges as a by-product of the poverty-punishment nexus; the state structures and participates in this legerdemain through financial doubledealing-disparate and contradictory economic entanglements that redistribute welfare resources from individuals to the criminal legal system and its institutional affiliates. These FDDs allow some government agencies to issue monetary benefits that foster Bryan Sykes and Becky Pettit's (2015) findings of system inclusion: veterans benefits, Supplemental Nutrition Assistance Program (SNAP) benefits, Temporary Assistance for Needy Families (TANF) benefits, unemployment assistance, social security income or disability, and so on. Other state entities, however, issue monetary penalties that engender Sarah Brayne's (2014) system avoidance: criminal legal system debt by way of monetary sanctions, wage-tax-commissary garnishments, child-support arrears, and so on. FDD allows local, state, and federal governments to draw from the same underlying source of economic support for poor individuals and families: the social safety net and other publicprivate benefits.

Figure 1 displays our theoretical model of micro and macro FDD in America. Wacquant (2009) argues, and other scholars find (see Ingraham 2020; Saez and Zucman 2019; Beckett and Western 2001), that state and federal governments allocate relative and disproportionate resources to social welfare (left hand) and criminal legal system functions (right hand). However, we contend that when social safety net resources are directly distributed to the poor and indigent, who may be ensnared in criminal court proceedings or probation supervision, the imposition of monetary sanctions (process \#1 in figure 1) may facilitate an additional redistribution of social welfare funds via criminal courts, representing one

1. See also the work of Bourdieu (1994) on state operations, which Wacquant (2009) attributes to this theoretical framework. 
Figure 1. A Theoretical Model of Micro and Macro Financial Double Dealing (FDD)

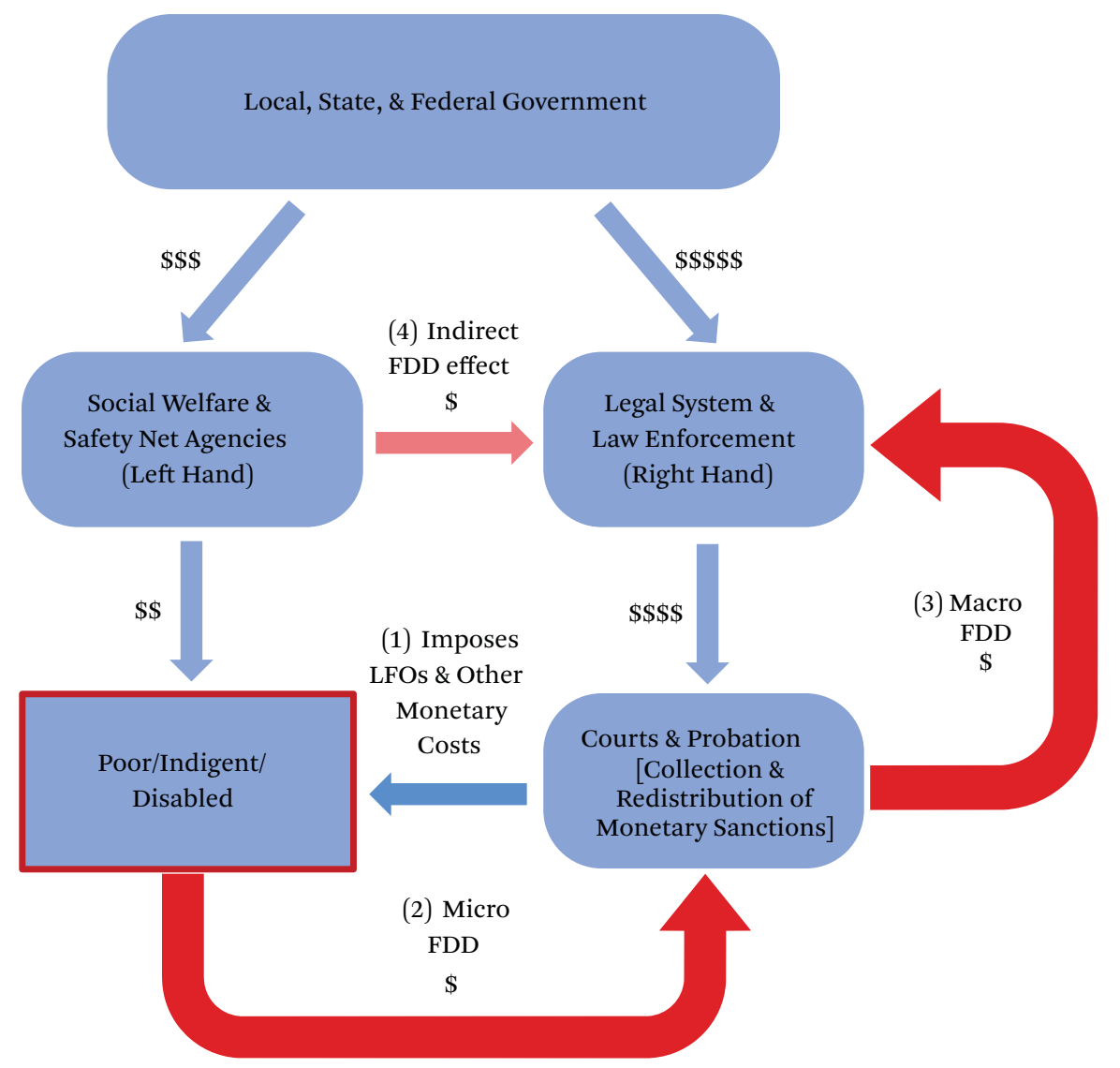

Source: Authors' theoretical conceptualization.

Note: Dollar signs are not to scale of federal, state, or local fiscal apportionment, as well as individual payment amounts; instead, these dollar signs represent the disproportionate flow of financial revenue from governments to individuals to institutions (micro FDD), and the financial dynamics inherent in the collection and redistribution of monetary sanctions, inter- and intra-institutionally (macro FDD), given state statutes that govern the dispersal of collected LFOs to other agencies and institutions.

form of FDD at the micro, individual level (process \#2 in figure 1). An additional form of FDD takes place at the macro level (process \#3 in figure 1), given that state statutes may direct the court or probation office to collect and allocate monetary sanctions to other criminal justice affiliates and agencies via a host of other costs, fees, special funds, and penalties (such as police unions, 911 operations, and emergency medical technician funds) (Harris, Evans, and Beckett 2010; Harris 2016; Friedman and Pattillo 2019; Pattillo and Kirk 2021, 2020; Verma and Sykes 2022, this volume). Taken together, the process of FDD can be theoretically interpreted as an economic backfilling of criminal justice operations, allowing the state to create an indirect feedback loop (process \#4 in figure 1) that enables the right hand of the state to usurp additional social welfare resources from the left hand via people on public assistance who are caught in the criminal justice web. Because criminal justice operations have become increasingly hybridized and have made steady advancements beyond criminal law and into administrative and civil law (Verma and Sykes 2022, this volume), resulting in a shadow carceral state (Beckett and $\mathrm{Mu}$ rakawa 2012), the collection of monetary sanc- 
tions from people on public assistance is likely to result in macro-level FDD among a variety of institutions, with collected revenue going to a host of different state agencies and funds (see O'Neill, Smith, and Kennedy 2022, this volume).

Although the analyses to come will focus on the redistribution of welfare resources to the criminal legal system through the imposition of legal financial debt, this process can be understood as one of multiple manifestations of FDDs by the state. The child-support system, for instance, is another institution that relies on the imposition of monetary penalties to recover welfare expenditures (Wacquant 2010; Gustafson 2012; Edin and Lein 1997). In the mid-1970s, the child-support system was restructured to mandate families receiving public benefits participate in programs aimed at recovering child-support payments to limit the government's distribution of cash welfare (Cozzolino 2018; Farrell, Glosser, and Gardiner 2003; Turetsky and Waller 2020). The retooling of child support to collect payments often employed punitive strategies to recover remittances of these public benefits to the poor (Solomon-Fears, Smith, and Berry 2012; Turetsky 2005; Gustafson 2012; Edin and Lein 1997). Welfare and child-support reforms have been justified as an effort to refocus the financial responsibility of children toward their noncustodial fathers, who were seen as eschewing their financial obligations (Edin and Kefalas 2005; Edin et al. 2019; Edin and Nelson 2013; Haney 2018; Pleggenkuhle 2018; Turetsky and Waller 2020; Wilson 1987). Nonetheless, the use of state agencies tasked with dispersing social welfare benefits and relying on family courts to collect child support while using criminal courts to punish welfare fraud cases, represent but one form of FDD by the state.

The identification and analysis of FDD reveals how the left and right hands of the state work to magnify inequality by providing public assistance to those experiencing poverty while financially punishing people living at the economic margins. These programs are useful because they are fungible-a dollar not spent on food, health care, or other goods and services is a dollar a person at the economic margin may be able to spend elsewhere. However, the fun- gibility of inequality-reducing programs also constitutes a vulnerability; benefits can be offset by punishment costs and payments. FDD in turn deepens and extends the poverty and marginalization for people already living at the margins. Thus, social safety net contributions are funneled back to the state via punishment and surveillance mechanisms. In the following analyses, we demonstrate how micro-level FDD occurs for people and families receiving cash and noncash public assistance.

\section{DATA}

To explore the relationship between public assistance and monetary sanctions, we rely on data from two sources. First, we leverage data from the 2019 Survey of Household Economics and Decisionmaking (SHED). Developed by the Federal Reserve Board and collected by the U.S. Federal Reserve, this nationwide survey investigates how receipt of cash and noncash assistance from the social safety net is associated with court-ordered debt. A private consumer research firm, Ipsos, administered the survey to a nationally representative, probabilitybased online panel. After selecting respondents using address-based sampling techniques, Ipsos curated a final pool of potential SHED participants. From this pool, Ipsos obtained a final-stage completion (or response) rate of 61.2 percent, resulting in a final sample of 12,173 respondents.

The SHED survey contains detailed questions about income, retirement funds, wealth accumulation, demographic background, public assistance and social safety net participation, criminal justice contact, exposure to crime, and, principally for our purposes, a measure of monetary sanctions. The survey was completed online, and adults without a computer or internet were provided these tools. The median time to complete the survey was nineteen minutes (for additional detail, see Federal Reserve 2020). The survey item about courtordered debt is limited to a dichotomous measure of whether the respondent or their immediate family member has unpaid legal expenses, fines, fees, or court costs. Unfortunately, numerical estimates of monetary sanctions imposed and paid were not collected.

To remedy this issue, we draw on novel data 
collected during the Multi-State Study of Monetary Sanctions (see Harris, Pattillo, and Sykes 2022, this volume). As a part of the study, survey data were collected from individuals for whom criminal legal system related debt was imposed. These surveys contained information on the amounts of monetary sanctions, whether a person has paid the debt, their criminal legal history, as well as whether the person receives public assistance. A total of 519 people were interviewed across our eight states, and after we removed missing data on key measures and data from Texas, due to Institutional Review Board regulations about matching these data with other sources, our analytic sample was reduced to 303 respondents.

Roughly half of the MSSMS sample is white (52.2 percent), and over a third of the sample is Black (34.7 percent). The sample is educationally advantaged, more than 83 percent having at least a high school diploma. Two-thirds of the sample is male, and the average age is approximately twenty-four. Half of the participants have never been married, and about 47 percent are parents to minor children. About 49 percent are employed, with considerable variation in their reported incomes. Approximately 95 percent report being incarcerated at some point in their lives, and have more than twice as many misdemeanor convictions (7.0), on average, than felony convictions (3.4).

We use these data, collectively, to investigate the risk of FDD among individuals and families that receive public assistance and were assessed a monetary sanction.

\section{MEASURES AND METHODS}

Given our use of two datasets to explore the association between public assistance and criminal justice debt, we rely on several different dependent measures to demonstrate the process of micro-FDD in America.

\section{Main Dependent Variables}

The SHED main dependent variable focuses on whether the respondent or their family has outstanding monetary sanctions. Specifically, the question is "Do you or someone in your immediate family currently have any unpaid legal expenses, fines, fees, or court costs?" Although this measure includes unpaid legal expenses, it is possible that the term includes public defender fees and costs as legal financial obligations (see Harris, Evans, and Beckett 2010). This question captures national exposure to a particular set of monetary sanctions.

The MSSMS dependent variables, on the other hand, focus on three questions that collectively establish the presence and extent of FDD. The first dependent variable is the amount of assessed LFOs and is constructed from answers to the survey question "About how much were you assessed in legal financial obligations?" We use this measure to estimate whether persons who receive public assistance receive lower amounts of LFOs. The second dependent variable is ability to pay LFOs and is constructed from answers to the survey question "Have you made any payments toward your LFOs?" We use it to capture whether any of the court-ordered debt has been paid, as a key feature of FDD is the ability of persons on public assistance that have criminal legal system debt to apportion their limited resources to the state. The third dependent variable is the amount paid down on LFO and is constructed from answers to the survey question "About how much have you paid of your LFOs (in dollars)?" We use it to estimate differences in amounts repaid by persons with and without public assistance.

\section{Main Independent Variables}

The focal independent variables in the SHED analysis are whether the respondent or their partner received any public assistance. We disaggregated this measure into two concepts. The first entailed any cash public assistance-Social Security (SS), Social Security Income (SSI), TANF or welfare payments, Unemployment Income, and public pension. The second was any noncash public assistance-SNAP; Special Supplemental Nutrition Program for Women, Infant, and Children (WIC); Housing Assistance Subsidies (Section 8); and receipt of free lunches. We split any public assistance into these two distinct measures to explore whether the type of public assistance (cash or noncash) matters for the risk of FDD.

We also used two main independent variables in the MSSMS analysis. First, receipt of any public assistance is a binary variable that cap- 
tures whether the respondent received SSI, SSDI, TANF, SNAP, WIC, Veterans Affairs (VA) benefits, or housing assistance, much like the SHED data. If the participant replied affirmatively to any of these six measures, they were coded as in receipt of public assistance. The second variable is a coder-computed and ordered family risk score. We used what Philipp Mayring (2001) terms generalization to turn qualitative interview data into categories for quantitative analysis (see also Srnka and Koeszegi 2007). This novel approach allowed us to investigate the extent to which an individual's family unit is at risk of FDD. We developed this variable in multiple coding phases through a deductive-inductive approach, and created an initial list of analytic operations and conceptions of family risk, which we refined as new categories arose inductively (Miles and Huberman 1994).

A team of three researchers analyzed the participants' interview answers to the question about receipt of public assistance. This openended question enabled participants to provide information about their receipt of public assistance, as well as of public assistance by members in their family unit. In combing through the in-depth interview data, the three researchers considered the ways in which family risk emerged in both presence and severity and developed thematic categories that captured the full range of data (Bradley 1993). This exercise was first performed independently by each researcher and then discussed with the entire research team for interrater reliability (Conger 1998). This process led to a robust conversation of categorical identification (Schilling 2006). Resulting from this practice was the creation of the family risk score variable. If a participant fell into multiple categories, the highest score was selected. The higher the score, the greater the risk of FDD for participants or their fami- lies. The final categorical risk categories were as follows:

0 (Reference) - participants and their families do not receive public assistance

1-participants or their families have applied for public assistance but were denied

2-participants or their families recently lost their public assistance

3-participants or their families have applied for public assistance and are still awaiting a decision

4-participants' families receive public assistance

5-participants themselves receive public assistance (TANF, SNAP/EBT, SSI, SSDI, VA-related benefits ${ }^{2}$

\section{Control Variables}

The SHED and MSSMS data contain complementary sets of demographic, economic, and criminal legal measures. For instance, both the SHED and MSSMS data contain similar criminal justice (previous incarceration) and sociodemographic (racial, educational, marital status, age, employment, and family composition) measures. Slight differences in questions about the respondent's gender (the MSSMS includes transgender), income classifications, criminal justice contact (the MSSMS contains a count of felonies and misdemeanors), and crime (the SHED data contain a measure of violent crime exposure) differentiate the two surveys. However, these differences do not undermine the empirical analyses presented.

\section{ANALYTIC STRATEGY}

We use several statistical methods to estimate the association between receipt of public assistance and criminal legal system debt. First,

2. The coding team debated as to whether persons who stated receiving public assistance in the form of health insurance or housing assistance should be coded as Risk Category 5 because such benefits are provided in the form of goods and services. The team ultimately agreed that they should be included in this risk category, given that receipt of such provisions, theoretically, affords participants monetary resources they would not otherwise have to pay monetary sanctions. Stated another way, if individuals lost such benefits, they would have less money to pay LFOs. To code participants whose families receive public assistance, we included participants who explicitly state that their relatives share those resources with them, and those who explicitly state that their relatives have helped or plan to help them pay for their LFOs while receiving public assistance. 
to assess the scope of risk nationally, we use logistic regression models to estimate the odds that receipt of any public assistance is associated with outstanding monetary sanctions owed using the SHED data (figure 2). Additionally, we use these models to assess whether the type of public assistance benefits (cash receipt or noncash program participation) matters for one's risk of owing monetary sanctions. If these two types of public assistance do not differ nationally, then collapsing these measures in the MSSMS data is valid for subsequent analyses.

Second, because our MSSMS measure of LFOs is a categorical, ordinal variable, we use ordered probit models to estimate the probability that individuals and families receiving public assistance are assessed at similar levels of LFOs (table 3). Furthermore, because we are also interested in whether any of the LFOs have been paid, we use probit models to estimate the relationship between receipt of public assistance and payment of LFOs (table 4). For both sets of models, we first run models controlling only for criminal legal measures and then additional models controlling for the suite of other criminal legal and social background measures. Last, given our interest in estimating the actual dollar values of LFO payments, we use ordinary least squares regression, where the dependent variable (LFO amount paid) adds $\$ 1$ to all participants and then logs the measure (table 5) to ease interpretation of percentage differences.

\section{FINDINGS}

Table 1 (SHED) and table 2 (MSSMS) present descriptive statistics from each data source. Table 1 shows that, nationally, a little more than 6 percent of the U.S. population had criminal justice debt in 2019. Approximately 43 percent received some form of public assistance, approximately 35.2 percent receiving cash and 13.6 percent receiving noncash.

Comparatively, table 2 shows that nearly 60 percent of participants are on public assistance. Additionally, although the MSSMS measure of monetary sanctions is different from the SHED measure, we find considerable heterogeneity in the LFO amount assessed. Although fewer than seven-tenths of 1 percent of the participants say they were not assessed any LFOs, about half reported being assessed LFOs of $\$ 5,000$ or less, and approximately onequarter reported being assessed LFOs in excess of $\$ 10,000$.

Although LFO assessments represent the court's order for payment, two additional measures convey compliance with paying monetary sanctions. First, approximately 70 percent of participants indicate that they have paid something toward their LFOs. Second, the average amount paid is approximately $\$ 4,000$.

To examine FDD, we rely on two measures

Table 1. Population Weighted Descriptive Statistics of Measures from the SHED Data

\begin{tabular}{llll}
\hline Variables & Mean & $\mathrm{N}$
\end{tabular}

\section{Dependent variables}

Have any criminal justice debt

$\begin{array}{lll}0.063 & 0.244 & 12,135\end{array}$

\section{Independent variables}

Any public assistance (PA)

$\begin{array}{llr}0.426 & 0.495 & 12,173 \\ 0.352 & 0.478 & 12,173 \\ 0.265 & 0.441 & 12,127 \\ 0.048 & 0.214 & 12,117 \\ 0.024 & 0.153 & 12,127 \\ 0.190 & 0.392 & 12,137 \\ 0.136 & 0.343 & 12,173 \\ 0.096 & 0.295 & 12,139 \\ 0.096 & 0.295 & 2,838 \\ 0.030 & 0.171 & 12,148 \\ 0.201 & 0.401 & 2,841\end{array}$

Any cash public assistance

Social Security

Social Security Income, TANF, Welfare

Unemployment Income

Pension

Any noncash public assistance

SNAP

WIC

Housing assistance

Free lunch

0.201

0.401

2,841 
Table 1. (continued)

\begin{tabular}{|c|c|c|c|}
\hline Variables & Mean & SD & $\mathrm{N}$ \\
\hline \multicolumn{4}{|l|}{ Control variables } \\
\hline Age & 48.215 & 17.417 & 12,173 \\
\hline \multicolumn{4}{|l|}{ Race-ethnicity } \\
\hline Non-Hispanic White & 0.636 & 0.481 & 12,173 \\
\hline Non-Hispanic Black & 0.119 & 0.324 & 12,173 \\
\hline Hispanic & 0.163 & 0.369 & 12,173 \\
\hline Non-Hispanic Other & 0.068 & 0.252 & 12,173 \\
\hline Non-Hispanic multiracial & 0.014 & 0.119 & 12,173 \\
\hline \multicolumn{4}{|l|}{ Education } \\
\hline Less than high school education & 0.102 & 0.302 & 12,173 \\
\hline High school diploma & 0.282 & 0.450 & 12,173 \\
\hline Some college & 0.616 & 0.486 & 12,173 \\
\hline \multicolumn{4}{|l|}{ Gender } \\
\hline Male & 0.481 & 0.500 & 12,173 \\
\hline Female & 0.519 & 0.500 & 12,173 \\
\hline \multicolumn{4}{|l|}{ Marital status } \\
\hline Married & 0.562 & 0.496 & 12,173 \\
\hline Living with partner & 0.079 & 0.270 & 12,173 \\
\hline Separated or divorced & 0.109 & 0.312 & 12,173 \\
\hline Widowed & 0.041 & 0.197 & 12,173 \\
\hline Never married, single & 0.210 & 0.407 & 12,173 \\
\hline Household size & 2.660 & 1.490 & 12,173 \\
\hline Unemployed & 0.353 & 0.478 & 12,173 \\
\hline \multicolumn{4}{|l|}{ Household income } \\
\hline Income: $<\$ 20,000$ & 0.103 & 0.304 & 12,173 \\
\hline Income: $\$ 20,000-29,999$ & 0.069 & 0.254 & 12,173 \\
\hline Income: $\$ 30,000-39,999$ & 0.075 & 0.264 & 12,173 \\
\hline Income: $\$ 40,000-49,999$ & 0.076 & 0.265 & 12,173 \\
\hline Income: $\$ 50,000-59,999$ & 0.074 & 0.261 & 12,173 \\
\hline Income: $\$ 60,000-74,999$ & 0.095 & 0.293 & 12,173 \\
\hline Income: $\$ 75,000-84,999$ & 0.069 & 0.254 & 12,173 \\
\hline Income: $\$ 85,000-99,999$ & 0.068 & 0.251 & 12,173 \\
\hline Income: $\$ 100,000^{+}$ & 0.371 & 0.483 & 12,173 \\
\hline Metro & 0.867 & 0.340 & 12,173 \\
\hline \multicolumn{4}{|l|}{ Region } \\
\hline New England & 0.046 & 0.210 & 12,173 \\
\hline Mid-Atlantic & 0.128 & 0.335 & 12,173 \\
\hline East-North Central & 0.144 & 0.351 & 12,173 \\
\hline West-North Central & 0.065 & 0.246 & 12,173 \\
\hline South-Atlantic & 0.203 & 0.402 & 12,173 \\
\hline East-South Central & 0.050 & 0.217 & 12,173 \\
\hline West-South Central & 0.126 & 0.332 & 12,173 \\
\hline Mountain & 0.076 & 0.265 & 12,173 \\
\hline Pacific & 0.162 & 0.368 & 12,173 \\
\hline Victim of violent crime & 0.087 & 0.281 & 12,150 \\
\hline Immediate family member ever incarcerated & 0.219 & 0.414 & 12,131 \\
\hline
\end{tabular}

Source: Authors' tabulation based on 2019 SHED data (Federal Reserve 2020). 
Table 2. Descriptive Statistics of Measures from the MSSMS

\begin{tabular}{|c|c|c|c|}
\hline Variables & Mean & SD & $\mathrm{N}$ \\
\hline \multicolumn{4}{|l|}{ Dependent variables } \\
\hline \multicolumn{4}{|l|}{ LFO Assessed } \\
\hline LFO assessed: 0 & 0.007 & 0.081 & 303 \\
\hline LFO assessed: $<\$ 500$ & 0.102 & 0.304 & 303 \\
\hline LFO assessed: $\$ 501-1,000$ & 0.079 & 0.271 & 303 \\
\hline LFO assessed: $\$ 1,001-2,000$ & 0.139 & 0.346 & 303 \\
\hline LFO assessed: $\$ 2,001-3,000$ & 0.119 & 0.324 & 303 \\
\hline LFO assessed: $\$ 3,001-4,000$ & 0.063 & 0.243 & 303 \\
\hline LFO assessed: $\$ 4,001-5,000$ & 0.059 & 0.237 & 303 \\
\hline LFO assessed: $\$ 5,001-6,000$ & 0.063 & 0.243 & 303 \\
\hline LFO assessed: $\$ 6,001-7,000$ & 0.030 & 0.170 & 303 \\
\hline LFO assessed: $\$ 7,001-8,000$ & 0.033 & 0.179 & 303 \\
\hline LFO assessed: $\$ 8,001-9,000$ & 0.023 & 0.150 & 303 \\
\hline LFO assessed: $\$ 9,001-10,000$ & 0.033 & 0.179 & 303 \\
\hline LFO assessed: More than $\$ 10,000$ & 0.251 & 0.434 & 303 \\
\hline Ever make a payment on LFO & 0.705 & 0.457 & 298 \\
\hline Total LFO amount paid & 4001.1 & 11075.7 & 193 \\
\hline \multicolumn{4}{|l|}{ Independent variables } \\
\hline Any public assistance (PA) & 0.601 & 0.491 & 303 \\
\hline Number of public assistance programs & 1.175 & 1.182 & 303 \\
\hline \multicolumn{4}{|l|}{ Family risk score } \\
\hline Family risk 0 (no risk) & 0.416 & 0.494 & 303 \\
\hline Family risk 1 (denied PA) & 0.017 & 0.128 & 303 \\
\hline Family risk 2 (no longer PA recipient) & 0.036 & 0.187 & 303 \\
\hline Family risk 3 (PA applicant) & 0.036 & 0.187 & 303 \\
\hline Family risk 4 (family receives PA) & 0.043 & 0.203 & 303 \\
\hline Family risk 5 (participant receives $\mathrm{PA}$ ) & 0.452 & 0.499 & 303 \\
\hline \multicolumn{4}{|l|}{ Control variables } \\
\hline Age & 23.73 & 12.01 & 303 \\
\hline \multicolumn{4}{|l|}{ Race-ethnicity } \\
\hline Non-Hispanic White & 0.522 & 0.500 & 303 \\
\hline Non-Hispanic Black & 0.347 & 0.477 & 303 \\
\hline Hispanic & 0.040 & 0.195 & 303 \\
\hline Non-Hispanic Other & 0.112 & 0.316 & 303 \\
\hline \multicolumn{4}{|l|}{ Education } \\
\hline Less than high school education & 0.168 & 0.375 & 303 \\
\hline High school diploma & 0.290 & 0.455 & 303 \\
\hline Some college & 0.541 & 0.499 & 303 \\
\hline \multicolumn{4}{|l|}{ Gender } \\
\hline Female & 0.310 & 0.463 & 303 \\
\hline Male & 0.680 & 0.467 & 303 \\
\hline Transgender & 0.007 & 0.081 & 303 \\
\hline \multicolumn{4}{|l|}{ Marital status } \\
\hline Married & 0.112 & 0.316 & 303 \\
\hline Living with partner & 0.096 & 0.295 & 303 \\
\hline Separated or divorced & 0.248 & 0.432 & 303 \\
\hline Widowed & 0.020 & 0.140 & 303 \\
\hline Never married, single & 0.521 & 0.500 & 303 \\
\hline
\end{tabular}


Table 2. (continued)

\begin{tabular}{lrrr}
\hline Variables & Mean & SD & $\mathrm{N}$ \\
\hline Parent & 0.465 & 0.500 & 303 \\
Employed & 0.485 & 0.501 & 303 \\
Income & & & \\
$\quad$ Income: $\langle 500$ & 0.050 & 0.217 & 303 \\
Income: $\$ 501-750$ & 0.046 & 0.210 & 303 \\
Income: $\$ 751-1,000$ & 0.066 & 0.249 & 303 \\
Income: $\$ 1,001-1,250$ & 0.043 & 0.203 & 303 \\
Income: $\$ 1,251-1,500$ & 0.040 & 0.195 & 303 \\
Income: $\$ 1,501-2,000$ & 0.063 & 0.243 & 303 \\
Income: $\$ 2,001-2,500$ & 0.063 & 0.243 & 303 \\
Income: $\$ 2,501-3,000$ & 0.033 & 0.179 & 303 \\
Income: $\$ 3,001-5,000$ & 0.056 & 0.231 & 303 \\
Income: $\$ 5,001-7,000$ & 0.017 & 0.128 & 303 \\
Income: More than $\$ 7,000$ & 0.013 & 0.114 & 303 \\
Number of felony convictions & 3.386 & 4.524 & 303 \\
Number of misdemeanor convictions & 7.020 & 14.311 & 303 \\
Ever incarcerated & 0.947 & 0.224 & 303 \\
\hline
\end{tabular}

Source: Authors' tabulation based on MSSMS data (Harris et al. 2018).

of government assistance. First, about three in five participants in the MSSMS data reported being on public assistance with an average enrollment in at least one government program. Second, the family risk of FDD is based on the participant and family's involvement with public programs. This measure is based on the coding of in-depth interviews, which reveal the context of public support. Approximately 41 percent of families do not receive public assistance (Risk Category 0), but the risk of FDD is heterogeneous; about 2 percent of participants belong to families that have applied for public assistance but were denied (Risk Category 1), and another 4 percent had recently lost their public assistance (Risk Category 2). Additionally, 4 percent of the participants said that they or their families applied for public assistance and were awaiting a decision (Risk Category 3), whereas another 4 percent rely on other family members who receive public assistance (Risk Category 4). More than 45 percent of families are in the highest category for risk of FDD, the participant reporting that they currently received some form of public assistance (Risk Category 5).

Figure 2 presents the log-odds of having any public assistance associated with criminal jus- tice debt, as well as distinctions between cash and noncash public assistance. The first barplot shows that the odds of having criminal justice debt are 51 percent $\left(=\mathrm{e}^{(0.415)}-1\right)$ higher for people with any public assistance than for those who are not enrolled in safety net programs. Controlling for violent crime exposure and previous incarceration history moderates this association (barplot 2); however, including measures of socioeconomic and demographic background measures (barplot 3) strengthen this association, indicating that the odds of having criminal justice debt are 78 percent $(=$ $\left.\mathrm{e}^{(0.579)}-1\right)$ higher for people on any form of public assistance.

Next, we examine whether the odds of having criminal justice debt depends on the types of public transfers a person receives (that is, cash versus noncash). Barplots 4 through 6 present estimates of the association between criminal justice debt and cash support public transfers, whereas barplots 7 through 9 assess the association between criminal justice debt and enrollment in noncash government programs. Indeed, there appears to be few distinguishing differences between types of public assistance. For instance, after controlling for criminal justice contact, crime, and social back- 
Figure 2. Log-Odds of Having Any Public Assistance Associated with Criminal Justice Debt

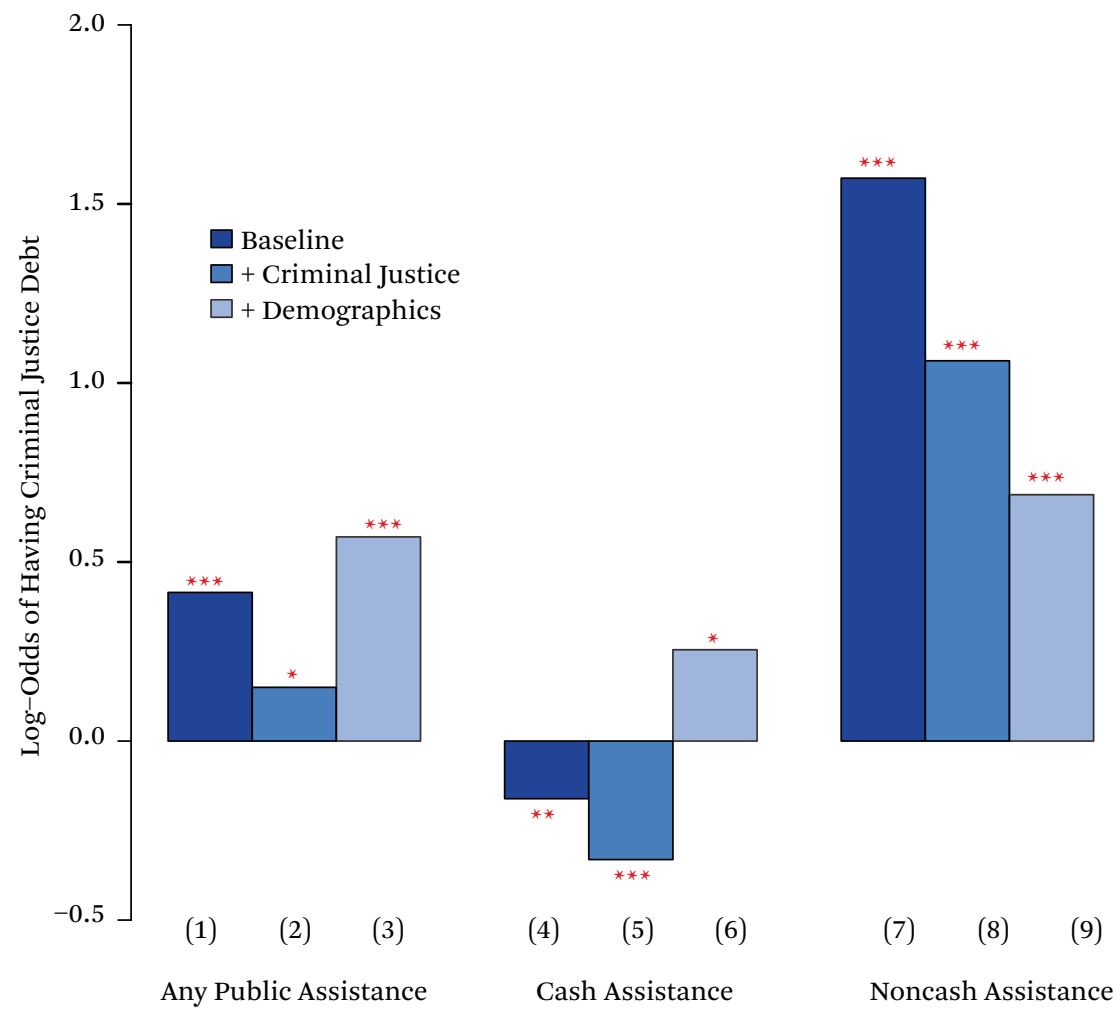

Source: Authors' tabulation based on 2019 SHED data (Federal Reserve 2020).

Note: Non-Hispanic Whites, married, less than a high school education, household income below $\$ 20,000$, and New England region are the reference categories. All models include state fixed effects, and standard errors are clustered on state. For full-model estimates, see online appendices 1 and 2. $\mathrm{N}=12,014$.

${ }^{* * *} p<.001,{ }^{* *} p<.01,{ }^{*} p<.05$

ground characteristics, barplot 6 shows that the odds of having criminal justice debt are 29 percent $\left(=\mathrm{e}^{(0.255)}-1\right)$ higher for people who receive cash support from the government $(p<.05)$. Comparatively, the association is much stronger $(p<.001)$ among people enrolled in noncash government programs (barplot 9), with their odds of owing criminal justice debt being 99 percent $\left(=\mathrm{e}^{(0.688)}-1\right)$ higher than people not enrolled in these programs. These findings from the SHED data suggest that distinguishing between cash and noncash public assistance may not be consequential when investigating the role of FDD within the criminal legal system.

Table 3 presents estimates from the ordered probit model that estimates the association between public assistance and the amount of
LFOs imposed. Models 1 through 3 pertain to participants who report receiving public assistance. Models 4 through 6 are based on the family risk score. None of the first three models provide evidence that individuals who receive public assistance have been assessed LFOs significantly different from individuals without public assistance. This holds true whether we control for criminal legal only measures (model 2), or the full set of criminal legal and social background controls (model 3).

The family risk score, however, tells a slightly different story. We do find suggestive and strong evidence that families with a higher risk of FDD have lower probabilities of having the same LFO amounts imposed on them. For instance, in model 4, without any control vari- 
Table 3. Probability that Individuals on Public Assistance and Families at Risk of FDD Have the Same Amounts of LFOs Imposed

\begin{tabular}{|c|c|c|c|c|c|c|}
\hline & (1) & (2) & (3) & (4) & (5) & (6) \\
\hline Public assistance & $\begin{array}{l}-0.000348 \\
(0.295)\end{array}$ & $\begin{array}{l}0.00627 \\
(0.290)\end{array}$ & $\begin{array}{l}-0.00463 \\
(0.186)\end{array}$ & & & \\
\hline Family risk 1 & & & & $\begin{array}{c}-0.0651 \\
(0.361)\end{array}$ & $\begin{array}{c}-0.198 \\
(0.443)\end{array}$ & $\begin{array}{c}-0.380 \\
(0.301)\end{array}$ \\
\hline Family risk 2 & & & & $\begin{array}{c}-0.449 \\
(0.302)\end{array}$ & $\begin{array}{c}-0.555^{+} \\
(0.319)\end{array}$ & $\begin{array}{c}-0.287 \\
(0.384)\end{array}$ \\
\hline Family risk 3 & & & & $\begin{array}{c}-0.0584 \\
(0.224)\end{array}$ & $\begin{array}{c}-0.365 \\
(0.382)\end{array}$ & $\begin{array}{c}-0.237^{+} \\
(0.143)\end{array}$ \\
\hline Family risk 4 & & & & $\begin{array}{c}-0.605^{+} \\
(0.345)\end{array}$ & $\begin{array}{c}-0.546 \\
(0.347)\end{array}$ & $\begin{array}{c}-0.285 \\
(0.361)\end{array}$ \\
\hline Family risk 5 & & & & $\begin{array}{c}-0.350 \\
(0.236)\end{array}$ & $\begin{array}{c}-0.447^{+} \\
(0.261)\end{array}$ & $\begin{array}{c}-0.443^{*} \\
(0.182)\end{array}$ \\
\hline Felony & & $\begin{array}{l}0.0651^{* * *} \\
(0.0177)\end{array}$ & $\begin{array}{l}0.0703^{* * *} \\
(0.0190)\end{array}$ & & $\begin{array}{l}0.0672^{* *} \\
(0.0211)\end{array}$ & $\begin{array}{l}0.0735^{* * *} \\
(0.0195)\end{array}$ \\
\hline Misdemeanors & & $\begin{array}{c}0.0158^{+} \\
(0.00912)\end{array}$ & $\begin{array}{c}0.0182^{*} \\
(0.00759)\end{array}$ & & $\begin{array}{c}0.0173^{+} \\
(0.00945)\end{array}$ & $\begin{array}{c}0.0199^{* *} \\
(0.00750)\end{array}$ \\
\hline Ever incarcerated & & $\begin{array}{c}0.574^{*} \\
(0.289)\end{array}$ & $\begin{array}{l}0.777^{* *} \\
(0.240)\end{array}$ & & $\begin{array}{l}0.654^{* *} \\
(0.239)\end{array}$ & $\begin{array}{l}0.780^{* * *} \\
(0.206)\end{array}$ \\
\hline Male & & & $\begin{array}{c}-0.258^{*} \\
(0.107)\end{array}$ & & & $\begin{array}{c}-0.289^{* *} \\
(0.111)\end{array}$ \\
\hline Employed & & & $\begin{array}{c}0.182 \\
(0.281)\end{array}$ & & & $\begin{array}{c}0.164 \\
(0.222)\end{array}$ \\
\hline Married & & & $\begin{array}{c}0.0633 \\
(0.0826)\end{array}$ & & & $\begin{array}{c}0.128^{+} \\
(0.0692)\end{array}$ \\
\hline Cohabiting & & & $\begin{array}{c}-0.230 \\
(0.327)\end{array}$ & & & $\begin{array}{c}-0.187 \\
(0.311)\end{array}$ \\
\hline Separated or divorced & & & $\begin{array}{c}-0.0717 \\
(0.148)\end{array}$ & & & $\begin{array}{c}-0.0614 \\
(0.143)\end{array}$ \\
\hline Widowed & & & $\begin{array}{c}0.643 \\
(0.519)\end{array}$ & & & $\begin{array}{c}0.749 \\
(0.503)\end{array}$ \\
\hline Age & & & $\begin{array}{c}-0.000332 \\
(0.00263)\end{array}$ & & & $\begin{array}{c}0.00129 \\
(0.00307)\end{array}$ \\
\hline Non-Hispanic Black & & & $\begin{array}{c}-0.422^{* *} \\
(0.129)\end{array}$ & & & $\begin{array}{c}-0.431^{* *} \\
(0.133)\end{array}$ \\
\hline Hispanic & & & $\begin{array}{c}0.684 \\
(0.433)\end{array}$ & & & $\begin{array}{c}0.785^{+} \\
(0.440)\end{array}$ \\
\hline Non-Hispanic Other & & & $\begin{array}{l}0.0621 \\
(0.337)\end{array}$ & & & $\begin{array}{c}0.0520 \\
(0.349)\end{array}$ \\
\hline High school & & & $\begin{array}{c}0.00809 \\
(0.0668)\end{array}$ & & & $\begin{array}{c}0.00117 \\
(0.0715)\end{array}$ \\
\hline Some college & & & $\begin{array}{l}0.306^{*} \\
(0.145)\end{array}$ & & & $\begin{array}{c}0.321^{+} \\
(0.173)\end{array}$ \\
\hline Number of children & & & $\begin{array}{l}-0.00994 \\
(0.228)\end{array}$ & & & $\begin{array}{c}-0.0379 \\
(0.244)\end{array}$ \\
\hline Income: $<\$ 501-750$ & & & $\begin{array}{c}0.310 \\
(0.370)\end{array}$ & & & $\begin{array}{c}0.319 \\
(0.324)\end{array}$ \\
\hline
\end{tabular}


Table 3. (continued)

\begin{tabular}{|c|c|c|c|c|c|c|}
\hline & (1) & (2) & (3) & (4) & (5) & (6) \\
\hline Inc.: $\$ 751-1,000$ & & & $\begin{array}{c}-0.193 \\
(0.396)\end{array}$ & & & $\begin{array}{c}-0.208 \\
(0.340)\end{array}$ \\
\hline Inc.: $\$ 1,001-1,250$ & & & $\begin{array}{c}0.425 \\
(0.472)\end{array}$ & & & $\begin{array}{c}0.393 \\
(0.410)\end{array}$ \\
\hline Inc.: $\$ 1,251-1,500$ & & & $\begin{array}{c}0.985^{+} \\
(0.511)\end{array}$ & & & $\begin{array}{c}0.876^{+} \\
(0.495)\end{array}$ \\
\hline Inc.: $\$ 1,501-2,000$ & & & $\begin{array}{c}-0.187 \\
(0.334)\end{array}$ & & & $\begin{array}{c}-0.218 \\
(0.319)\end{array}$ \\
\hline Inc.: $\$ 2,001-2,500$ & & & $\begin{array}{c}0.0828 \\
(0.274)\end{array}$ & & & $\begin{array}{c}0.0335 \\
(0.286)\end{array}$ \\
\hline Inc.: $\$ 2,501-3,000$ & & & $\begin{array}{c}0.572 \\
(0.370)\end{array}$ & & & $\begin{array}{c}0.356 \\
(0.231)\end{array}$ \\
\hline Inc.: $\$ 3,001-5,000$ & & & $\begin{array}{l}0.693^{* *} \\
(0.263)\end{array}$ & & & $\begin{array}{c}0.596^{*} \\
(0.271)\end{array}$ \\
\hline Inc.: $\$ 5,001-7,000$ & & & $\begin{array}{c}0.0701 \\
(0.628)\end{array}$ & & & $\begin{array}{c}-0.0824 \\
(0.509)\end{array}$ \\
\hline Inc.: $\$ 7,001^{+}$ & & & $\begin{array}{c}-0.716 \\
(0.917)\end{array}$ & & & $\begin{array}{c}-0.883 \\
(0.874)\end{array}$ \\
\hline /cut1 & $\begin{array}{l}-2.479 * * * \\
(0.302)\end{array}$ & $\begin{array}{l}-1.709 * * * \\
(0.319)\end{array}$ & $\begin{array}{c}-1.662^{* * *} \\
(0.250)\end{array}$ & $\begin{array}{l}-2.731^{* * *} \\
(0.312)\end{array}$ & $\begin{array}{l}-1.951^{* * *} \\
(0.227)\end{array}$ & $\begin{array}{l}-1.947^{* * *} \\
(0.212)\end{array}$ \\
\hline /cut2 & $\begin{array}{c}-1.233^{* * *} \\
(0.268)\end{array}$ & $\begin{array}{c}-0.439 \\
(0.381)\end{array}$ & $\begin{array}{c}-0.312 \\
(0.329)\end{array}$ & $\begin{array}{c}-1.459 * * * \\
(0.228)\end{array}$ & $\begin{array}{c}-0.645^{*} \\
(0.260)\end{array}$ & $\begin{array}{c}-0.558^{+} \\
(0.299)\end{array}$ \\
\hline /cut3 & $\begin{array}{c}-0.885^{* * *} \\
(0.259)\end{array}$ & $\begin{array}{c}-0.0761 \\
(0.331)\end{array}$ & $\begin{array}{c}0.0801 \\
(0.273)\end{array}$ & $\begin{array}{l}-1.104^{* * *} \\
(0.219)\end{array}$ & $\begin{array}{c}-0.272 \\
(0.189)\end{array}$ & $\begin{array}{c}-0.158 \\
(0.229)\end{array}$ \\
\hline /cut4 & $\begin{array}{c}-0.449^{+} \\
(0.241)\end{array}$ & $\begin{array}{c}0.380 \\
(0.274)\end{array}$ & $\begin{array}{l}0.572^{* *} \\
(0.209)\end{array}$ & $\begin{array}{c}-0.659 * * \\
(0.203)\end{array}$ & $\begin{array}{c}0.197 \\
(0.130)\end{array}$ & $\begin{array}{c}0.343^{+} \\
(0.182)\end{array}$ \\
\hline /cut5 & $\begin{array}{c}-0.137 \\
(0.314)\end{array}$ & $\begin{array}{l}0.707^{*} \\
(0.312)\end{array}$ & $\begin{array}{l}0.930^{* * *} \\
(0.212)\end{array}$ & $\begin{array}{c}-0.344 \\
(0.274)\end{array}$ & $\begin{array}{l}0.529 * * * \\
(0.144)\end{array}$ & $\begin{array}{l}0.705^{* * *} \\
(0.162)\end{array}$ \\
\hline /cut6 & $\begin{array}{l}0.0205 \\
(0.299)\end{array}$ & $\begin{array}{l}0.875^{* *} \\
(0.291)\end{array}$ & $\begin{array}{l}1.117^{* * *} \\
(0.186)\end{array}$ & $\begin{array}{c}-0.184 \\
(0.256)\end{array}$ & $\begin{array}{l}0.700^{* * *} \\
(0.120)\end{array}$ & $\begin{array}{l}0.893^{* * *} \\
(0.142)\end{array}$ \\
\hline /cut7 & $\begin{array}{c}0.170 \\
(0.324)\end{array}$ & $\begin{array}{l}1.035^{* * *} \\
(0.311)\end{array}$ & $\begin{array}{l}1.294^{* * *} \\
(0.194)\end{array}$ & $\begin{array}{c}-0.0318 \\
(0.277)\end{array}$ & $\begin{array}{l}0.864^{* * *} \\
(0.139)\end{array}$ & $\begin{array}{l}1.073^{* * *} \\
(0.143)\end{array}$ \\
\hline /cut8 & $\begin{array}{c}0.333 \\
(0.307)\end{array}$ & $\begin{array}{l}1.208^{* * *} \\
(0.312)\end{array}$ & $\begin{array}{l}1.485^{* * *} \\
(0.212)\end{array}$ & $\begin{array}{c}0.134 \\
(0.256)\end{array}$ & $\begin{array}{l}1.042^{* * *} \\
(0.147)\end{array}$ & $\begin{array}{l}1.268^{* * *} \\
(0.169)\end{array}$ \\
\hline /cut9 & $\begin{array}{c}0.412 \\
(0.299)\end{array}$ & $\begin{array}{l}1.294^{* * *} \\
(0.321)\end{array}$ & $\begin{array}{l}1.580^{* * *} \\
(0.228)\end{array}$ & $\begin{array}{c}0.216 \\
(0.243)\end{array}$ & $\begin{array}{l}1.131^{* * *} \\
(0.155)\end{array}$ & $\begin{array}{l}1.364^{* * *} \\
(0.180)\end{array}$ \\
\hline /cut10 & $\begin{array}{c}0.504^{+} \\
(0.285)\end{array}$ & $\begin{array}{l}1.394^{* * *} \\
(0.320)\end{array}$ & $\begin{array}{l}1.691^{* * *} \\
(0.242)\end{array}$ & $\begin{array}{c}0.310 \\
(0.228)\end{array}$ & $\begin{array}{l}1.234^{* * *} \\
(0.159)\end{array}$ & $\begin{array}{l}1.477^{* * *} \\
(0.195)\end{array}$ \\
\hline /cut11 & $\begin{array}{l}0.571^{*} \\
(0.287)\end{array}$ & $\begin{array}{l}1.468^{* * *} \\
(0.326)\end{array}$ & $\begin{array}{l}1.774^{* * *} \\
(0.257)\end{array}$ & $\begin{array}{c}0.378^{+} \\
(0.228)\end{array}$ & $\begin{array}{l}1.309 * * * \\
(0.164)\end{array}$ & $\begin{array}{l}1.561^{* * *} \\
(0.205)\end{array}$ \\
\hline /cut12 & $\begin{array}{c}0.672^{*} \\
(0.299)\end{array}$ & $\begin{array}{l}1.579 * * * \\
(0.314)\end{array}$ & $\begin{array}{l}1.900^{* * *} \\
(0.247)\end{array}$ & $\begin{array}{c}0.480^{*} \\
(0.243)\end{array}$ & $\begin{array}{l}1.422^{* * *} \\
(0.153)\end{array}$ & $\begin{array}{l}1.689 * * * \\
(0.197)\end{array}$ \\
\hline Observations & 303 & 303 & 303 & 303 & 303 & 303 \\
\hline
\end{tabular}

Source: Authors' tabulation based on MSSW data (Harris et al. 2018).

Note: Non-Hispanic Whites, single, less than a high school education, and household income below $\$ 500$ per month are the reference categories. All models include state fixed effects, and standard errors are clustered on state. Standard errors in parentheses.

${ }^{* * *} p<.001,{ }^{* *} p<.01,{ }^{*} p<.05,{ }^{+} p<.10$ 
ables, the negative, moderate association $(\mathrm{B}=-0.605, p<.1)$ in families where another family member receives public assistance (Risk Category 4) is associated with a lower probability of receiving the same LFO amount as someone who is not at risk of FDD. Controlling for criminal legal measures (model 5) provides moderate evidence for the risk of FDD among families that have lost public assistance (Risk Category 2) and among families where the participant is the public assistance recipient (Risk Category 5). Once criminal legal history and social background are controlled for, the strongest evidence for FDD is that in families where the participant receives public assistance, there is a strong, negative association $(\mathrm{B}=-0.443$, $p<.05$ ). This indicates that these individuals and their family may be assessed smaller LFOs, but that reduced amount is nonzero.

Models 1 through 3 of table 4 display esti- mates from probit models of the association between participant receipt of public assistance and having paid any money toward one's LFOs. Although models 1 and 2 do not show any clear association, model 3 presents evidence that participant receipt of public assistance is negatively associated $(\mathrm{B}=-0.345, p<.05)$ with having made any payments on their LFO, net of criminal legal history and social background.

Models 4 through 6 present a similar story for families at risk of FDD. Across all models, families with the highest risk of FDD have a lower probability $(\mathrm{B}=-0.408, p<.001$, model 4$)$ of making payments on their LFOs than families where there is no risk of FDD. In fact, across all three models, controlling for criminal legal history and social background further decreases the chances $(\mathrm{B}=-0.460, p<.001$, model $6)$ that these families will make any payments on their LFOs.

Table 4. Probability that Individuals and Families at Risk of FDD Have Paid Any of their LFOs to Courts

\begin{tabular}{|c|c|c|c|c|c|c|}
\hline & (1) & (2) & (3) & (4) & (5) & (6) \\
\hline \multicolumn{7}{|l|}{ Variables } \\
\hline Public assistance & $\begin{array}{c}-0.284 \\
(0.193)\end{array}$ & $\begin{array}{c}-0.285 \\
(0.181)\end{array}$ & $\begin{array}{c}-0.345^{*} \\
(0.156)\end{array}$ & & & \\
\hline Family risk 1 & & & & $\begin{array}{c}-0.505 \\
(0.611)\end{array}$ & $\begin{array}{c}-0.568 \\
(0.625)\end{array}$ & $\begin{array}{c}-0.601 \\
(0.695)\end{array}$ \\
\hline Family risk 2 & & & & $\begin{array}{c}-0.759 \\
(0.598)\end{array}$ & $\begin{array}{c}-0.778 \\
(0.592)\end{array}$ & $\begin{array}{c}-0.714 \\
(0.577)\end{array}$ \\
\hline Family risk 3 & & & & $\begin{array}{c}-0.234 \\
(0.256)\end{array}$ & $\begin{array}{c}-0.370 \\
(0.270)\end{array}$ & $\begin{array}{c}-0.275 \\
(0.218)\end{array}$ \\
\hline Family risk 4 & & & & $\begin{array}{c}0.667 \\
(0.433)\end{array}$ & $\begin{array}{c}0.680 \\
(0.443)\end{array}$ & $\begin{array}{c}0.841 \\
(0.531)\end{array}$ \\
\hline Family risk 5 & & & & $\begin{array}{c}-0.408^{* * *} \\
(0.0763)\end{array}$ & $\begin{array}{l}-0.440^{* * *} \\
(0.0699)\end{array}$ & $\begin{array}{l}-0.460^{* * *} \\
(0.104)\end{array}$ \\
\hline Felony & & $\begin{array}{c}0.0197 \\
(0.0160)\end{array}$ & $\begin{array}{c}0.0240 \\
(0.0230)\end{array}$ & & $\begin{array}{c}0.0246 \\
(0.0151)\end{array}$ & $\begin{array}{c}0.0282 \\
(0.0229)\end{array}$ \\
\hline Misdemeanors & & $\begin{array}{c}0.00173 \\
(0.00708)\end{array}$ & $\begin{array}{c}0.00328 \\
(0.00714)\end{array}$ & & $\begin{array}{c}0.00258 \\
(0.00623)\end{array}$ & $\begin{array}{c}0.00398 \\
(0.00650)\end{array}$ \\
\hline Ever incarcerated & & $\begin{array}{c}0.323 \\
(0.296)\end{array}$ & $\begin{array}{c}0.488^{+} \\
(0.283)\end{array}$ & & $\begin{array}{c}0.399 \\
(0.346)\end{array}$ & $\begin{array}{c}0.522 \\
(0.358)\end{array}$ \\
\hline Male & & & $\begin{array}{c}-0.253 \\
(0.206)\end{array}$ & & & $\begin{array}{c}-0.235 \\
(0.214)\end{array}$ \\
\hline Employed & & & $\begin{array}{c}0.291 \\
(0.284)\end{array}$ & & & $\begin{array}{c}0.337 \\
(0.260)\end{array}$ \\
\hline Married & & & $\begin{array}{c}0.503 \\
(0.344)\end{array}$ & & & $\begin{array}{c}0.582^{+} \\
(0.341)\end{array}$ \\
\hline
\end{tabular}


Table 4. (continued)

\begin{tabular}{|c|c|c|c|c|c|c|}
\hline & (1) & (2) & (3) & (4) & (5) & (6) \\
\hline Cohabiting & & & $\begin{array}{c}-0.438^{* *} \\
(0.165)\end{array}$ & & & $\begin{array}{c}-0.407^{*} \\
(0.176)\end{array}$ \\
\hline Separated or divorced & & & $\begin{array}{c}-0.168 \\
(0.158)\end{array}$ & & & $\begin{array}{c}-0.171 \\
(0.138)\end{array}$ \\
\hline Widowed & & & $\begin{array}{l}- \\
-\end{array}$ & & & $\begin{array}{l}- \\
-\end{array}$ \\
\hline Age & & & $\begin{array}{c}0.00495 \\
(0.00482)\end{array}$ & & & $\begin{array}{c}0.00796 \\
(0.00519)\end{array}$ \\
\hline Non-Hispanic Black & & & $\begin{array}{c}0.0350 \\
(0.181)\end{array}$ & & & $\begin{array}{l}-0.00345 \\
(0.192)\end{array}$ \\
\hline Hispanic & & & $\begin{array}{r}-0.122 \\
(0.357)\end{array}$ & & & $\begin{array}{c}-0.0947 \\
(0.374)\end{array}$ \\
\hline Non-Hispanic Other & & & $\begin{array}{c}0.320^{+} \\
(0.167)\end{array}$ & & & $\begin{array}{c}0.291 \\
(0.188)\end{array}$ \\
\hline High school & & & $\begin{array}{c}0.226^{* *} \\
(0.0823)\end{array}$ & & & $\begin{array}{c}0.267^{*} \\
(0.125)\end{array}$ \\
\hline Some college & & & $\begin{array}{c}0.0132 \\
(0.199)\end{array}$ & & & $\begin{array}{c}0.103 \\
(0.230)\end{array}$ \\
\hline Number of children & & & $\begin{array}{c}0.148 \\
(0.290)\end{array}$ & & & $\begin{array}{c}0.159 \\
(0.274)\end{array}$ \\
\hline Income: $<\$ 501-750$ & & & $\begin{array}{r}-0.373 \\
(0.345)\end{array}$ & & & $\begin{array}{r}-0.331 \\
(0.335)\end{array}$ \\
\hline Income: $\$ 751-1,000$ & & & $\begin{array}{c}-0.694^{+} \\
(0.378)\end{array}$ & & & $\begin{array}{r}-0.727 \\
(0.453)\end{array}$ \\
\hline Income: $\$ 1,001-1,250$ & & & $\begin{array}{c}0.405 \\
(0.313)\end{array}$ & & & $\begin{array}{c}0.283 \\
(0.358)\end{array}$ \\
\hline Income: $\$ 1,251-1,500$ & & & $\begin{array}{c}0.328 \\
(0.710)\end{array}$ & & & $\begin{array}{c}0.259 \\
(0.693)\end{array}$ \\
\hline Income: $\$ 1,501-2,000$ & & & $\begin{array}{c}0.0991 \\
(0.515)\end{array}$ & & & $\begin{array}{c}0.0847 \\
(0.575)\end{array}$ \\
\hline Income: $\$ 2,001-2,500$ & & & $\begin{array}{c}-0.236 \\
(0.415)\end{array}$ & & & $\begin{array}{c}-0.162 \\
(0.389)\end{array}$ \\
\hline Income: $\$ 2,501-3,000$ & & & $\begin{array}{c}0.161 \\
(0.493)\end{array}$ & & & $\begin{array}{c}-0.185 \\
(0.496)\end{array}$ \\
\hline Income: $\$ 3,001-5,000$ & & & $\begin{array}{c}0.270 \\
(0.578)\end{array}$ & & & $\begin{array}{c}0.0298 \\
(0.548)\end{array}$ \\
\hline Income: $\$ 5,001-7,000$ & & & $\begin{array}{c}0.388 \\
(0.780)\end{array}$ & & & $\begin{array}{c}0.257 \\
(0.626)\end{array}$ \\
\hline Income: $\$ 7,001^{+}$ & & & $\begin{array}{c}-0.0703 \\
(1.138)\end{array}$ & & & $\begin{array}{r}-0.161 \\
(1.120)\end{array}$ \\
\hline Constant & $\begin{array}{l}0.715^{\text {***}} \\
(0.108)\end{array}$ & $\begin{array}{c}0.335 \\
(0.216)\end{array}$ & $\begin{array}{c}-0.0240 \\
(0.443)\end{array}$ & $\begin{array}{l}0.759^{* * *} \\
(0.100)\end{array}$ & $\begin{array}{c}0.307 \\
(0.363)\end{array}$ & $\begin{array}{r}-0.183 \\
(0.553)\end{array}$ \\
\hline Observations & 298 & 298 & 298 & 298 & 298 & 298 \\
\hline
\end{tabular}

Source: Authors' tabulation based on MSSW data (Harris et al. 2018).

Note: Non-Hispanic Whites, single, less than a high school education, and household income below $\$ 500$ per month are the reference categories. All models include state fixed effects, and standard errors are clustered on state. Standard errors in parentheses.

${ }^{* * *} p<.001,{ }^{* *} p<.01,{ }^{*} p<.05,{ }^{+} p<.10$ 
Last, table 5 displays estimates from the ordinary least squares regression of the association between receipt of government assistance and the amount of money paid to the court. Confirming findings from table 3 , models 3 and 4 of table 4 present moderate evidence $(p<.1)$ that participants receiving public assistance, and families at higher risk of FDD, have paid less on their LFOs than individuals and families not receiving public assistance. Curiously, model 6 shows that, after controlling for criminal legal history and social background, families that have applications for public assistance under review have paid more $(\mathrm{B}=1.326, p<.05)$ on their LFOs than people who do not receive public assistance. It could be that these individuals are concerned that their applications for assistance may be denied if they do not pay down their LFOs. Future research should explore this connection in more detail.

Table 5. OLS Regression of Logged LFO Payments to Court

\begin{tabular}{|c|c|c|c|c|c|c|}
\hline & (1) & (2) & (3) & (4) & (5) & (6) \\
\hline \multicolumn{7}{|l|}{ Variables } \\
\hline Public assistance & $\begin{array}{c}-0.295 \\
(0.335)\end{array}$ & $\begin{array}{c}-0.355 \\
(0.295)\end{array}$ & $\begin{array}{c}-0.409^{+} \\
(0.180)\end{array}$ & & & \\
\hline Family risk 1 & & & & $\begin{array}{c}-1.083 \\
(0.821)\end{array}$ & $\begin{array}{c}-0.944 \\
(0.868)\end{array}$ & $\begin{array}{c}-0.541^{+} \\
(0.259)\end{array}$ \\
\hline Family risk 2 & & & & $\begin{array}{c}-0.477 \\
(0.503)\end{array}$ & $\begin{array}{c}-0.388 \\
(0.524)\end{array}$ & $\begin{array}{c}0.128 \\
(0.771)\end{array}$ \\
\hline Family risk 3 & & & & $\begin{array}{c}0.715 \\
(0.647)\end{array}$ & $\begin{array}{c}0.724 \\
(0.598)\end{array}$ & $\begin{array}{c}1.326^{*} \\
(0.428)\end{array}$ \\
\hline Family risk 4 & & & & $\begin{array}{c}-0.789^{+} \\
(0.385)\end{array}$ & $\begin{array}{c}-0.638 \\
(0.341)\end{array}$ & $\begin{array}{l}0.0621 \\
(0.480)\end{array}$ \\
\hline Family risk 5 & & & & $\begin{array}{c}0.0690 \\
(0.299)\end{array}$ & $\begin{array}{c}0.0656 \\
(0.324)\end{array}$ & $\begin{array}{l}0.00189 \\
(0.311)\end{array}$ \\
\hline Felony & & $\begin{array}{c}0.0172 \\
(0.0310)\end{array}$ & $\begin{array}{c}-0.00355 \\
(0.0252)\end{array}$ & & $\begin{array}{c}0.00579 \\
(0.0297)\end{array}$ & $\begin{array}{r}-0.0166 \\
(0.0259)\end{array}$ \\
\hline Misdemeanors & & $\begin{array}{c}0.0348^{*} \\
(0.0110)\end{array}$ & $\begin{array}{r}0.0421^{* *} \\
(0.00879)\end{array}$ & & $\begin{array}{c}0.0337^{*} \\
(0.0113)\end{array}$ & $\begin{array}{c}0.0419^{* *} \\
(0.00897)\end{array}$ \\
\hline Ever incarcerated & & $\begin{array}{c}0.0861 \\
(0.227)\end{array}$ & $\begin{array}{c}0.173 \\
(0.235)\end{array}$ & & $\begin{array}{c}0.178 \\
(0.240)\end{array}$ & $\begin{array}{c}0.111 \\
(0.396)\end{array}$ \\
\hline Male & & & $\begin{array}{c}-0.404 \\
(0.448)\end{array}$ & & & $\begin{array}{c}-0.381 \\
(0.460)\end{array}$ \\
\hline Employed & & & $\begin{array}{c}0.329 \\
(0.257)\end{array}$ & & & $\begin{array}{c}0.396 \\
(0.283)\end{array}$ \\
\hline Married & & & $\begin{array}{c}-0.114 \\
(0.122)\end{array}$ & & & $\begin{array}{c}-0.167 \\
(0.116)\end{array}$ \\
\hline Cohabiting & & & $\begin{array}{c}-0.815 \\
(0.661)\end{array}$ & & & $\begin{array}{c}-0.800 \\
(0.671)\end{array}$ \\
\hline Separated, divorced & & & $\begin{array}{c}0.333 \\
(0.351)\end{array}$ & & & $\begin{array}{c}0.373 \\
(0.290)\end{array}$ \\
\hline Widowed & & & $\begin{array}{c}0.933 \\
(0.604)\end{array}$ & & & $\begin{array}{c}1.093 \\
(0.582)\end{array}$ \\
\hline Age & & & $\begin{array}{c}0.0291^{+} \\
(0.0139)\end{array}$ & & & $\begin{array}{c}0.0294^{+} \\
(0.0125)\end{array}$ \\
\hline Non-Hispanic Black & & & $\begin{array}{c}-0.489 \\
(0.264)\end{array}$ & & & $\begin{array}{c}-0.548 \\
(0.311)\end{array}$ \\
\hline Hispanic & & & $\begin{array}{c}-0.435^{+} \\
(0.216)\end{array}$ & & & $\begin{array}{c}-0.545 \\
(0.281) \\
\text { (continued) }\end{array}$ \\
\hline
\end{tabular}


Table 5. (continued)

\begin{tabular}{|c|c|c|c|c|c|c|}
\hline & (1) & (2) & (3) & (4) & (5) & (6) \\
\hline Non-Hispanic Other & & & $\begin{array}{c}-0.441 \\
(0.380)\end{array}$ & & & $\begin{array}{c}-0.321 \\
(0.419)\end{array}$ \\
\hline High school & & & $\begin{array}{c}0.320 \\
(0.383)\end{array}$ & & & $\begin{array}{c}0.313 \\
(0.392)\end{array}$ \\
\hline Some college & & & $\begin{array}{c}0.375 \\
(0.225)\end{array}$ & & & $\begin{array}{c}0.522^{*} \\
(0.213)\end{array}$ \\
\hline Number of children & & & $\begin{array}{c}-0.281 \\
(0.147)\end{array}$ & & & $\begin{array}{c}-0.258 \\
(0.136)\end{array}$ \\
\hline Income: $<\$ 501-750$ & & & $\begin{array}{c}-0.0971 \\
(0.486)\end{array}$ & & & $\begin{array}{l}0.217 \\
(0.398)\end{array}$ \\
\hline Income: $\$ 751-1,000$ & & & $\begin{array}{c}-1.163^{+} \\
(0.500)\end{array}$ & & & $\begin{array}{c}-1.070^{+} \\
(0.512)\end{array}$ \\
\hline Income: $\$ 1,001-1,250$ & & & $\begin{array}{c}0.424 \\
(0.353)\end{array}$ & & & $\begin{array}{c}0.428 \\
(0.370)\end{array}$ \\
\hline Income: $\$ 1,251-1,500$ & & & $\begin{array}{c}0.425 \\
(0.610)\end{array}$ & & & $\begin{array}{c}0.306 \\
(0.759)\end{array}$ \\
\hline Income: $\$ 1,501-2,000$ & & & $\begin{array}{c}0.331 \\
(0.516)\end{array}$ & & & $\begin{array}{c}0.409 \\
(0.594)\end{array}$ \\
\hline Income: $\$ 2,001-2,500$ & & & $\begin{array}{c}-0.640 \\
(0.571)\end{array}$ & & & $\begin{array}{c}-0.505 \\
(0.598)\end{array}$ \\
\hline Income: $\$ 2,501-3,000$ & & & $\begin{array}{c}1.624^{*} \\
(0.543)\end{array}$ & & & $\begin{array}{c}1.522^{*} \\
(0.539)\end{array}$ \\
\hline Income: $\$ 3,001-5,000$ & & & $\begin{array}{c}0.784 \\
(0.508)\end{array}$ & & & $\begin{array}{c}0.722 \\
(0.557)\end{array}$ \\
\hline Income: $\$ 5,001-7,000$ & & & $\begin{array}{c}0.916^{+} \\
(0.407)\end{array}$ & & & $\begin{array}{c}0.919^{+} \\
(0.395)\end{array}$ \\
\hline Income: $\$ 7,001^{+}$ & & & $\begin{array}{c}0.878 \\
(0.621)\end{array}$ & & & $\begin{array}{c}1.095 \\
(0.735)\end{array}$ \\
\hline Constant & $\begin{array}{l}7.108^{* * *} \\
(0.419)\end{array}$ & $\begin{array}{l}6.749 * * * \\
(0.425)\end{array}$ & $\begin{array}{l}6.081^{* * *} \\
(0.463)\end{array}$ & $\begin{array}{l}6.963^{* * *} \\
(0.391)\end{array}$ & $\begin{array}{l}6.518^{* * *} \\
(0.336)\end{array}$ & $\begin{array}{l}5.738^{* * *} \\
(0.507)\end{array}$ \\
\hline Observations & 193 & 193 & 193 & 193 & 193 & 193 \\
\hline $\mathrm{R}^{2}$ & 0.007 & 0.104 & 0.317 & 0.027 & 0.114 & 0.325 \\
\hline
\end{tabular}

Source: Authors' tabulation based on MSSW data (Harris et al. 2018).

Note: Non-Hispanic Whites, single, less than a high school education, and household income less than $\$ 500$ per month are the reference categories. All models include state fixed effects, and standard errors are clustered on state.

${ }^{* * *} p<.001,{ }^{* *} p<.01,{ }^{*} p<.05,{ }^{+} p<.10$

\section{DISCUSSION AND POLICY} IMPLICATIONS

Although many scholars have discussed the regressive interaction of monetary sanctions and public assistance, the motivation of this article is to move the conversation away from recognizing monetary sanctions as a collateral consequence of the penal system, and toward the rec- ognition that, when financial sanctions are applied to the poor, particularly those who are the recipients of public assistance, these sanctions act as an exponent of punishment by depriving individuals and communities of social safety net provisions (see also Harris 2016). Recent scholarship has helped clarify the struggles of reentry (Western 2018), echoing qualitative 
(Macleod 2009) and quantitative (Pager 2003; Pager and Lincoln 2005; Petitt and Lyons 2009) findings that a criminal record is an "absorbing status" (Maroto 2015) that profoundly reduces labor access and wealth generation (Sykes and Maroto 2016; Maroto and Sykes 2020). Our work contributes to scholarship on the feedback effects of poverty and LFOs by specifying how money is, often unwittingly, transferred from assistance programs to penal institutions in the imposition of monetary sanctions.

Findings from our analysis are also relevant for other articles in this volume and have specific policy implications. First, Mary Pattillo and her colleagues (2022) examine the relationship between the criminal legal system and housing stability. Although previous research has focused on the criminalization of homelessness and the impact of incarceration on housing stability, Pattillo and her coauthors argue that financial penalties affect the affordability of life necessities, leading to poor housing outcomes (such as housing instability or homelessness), which the authors refer to as the "instabilityLFO nexus" (p. 58). For example, they note that one participant, who could not afford housing, was expected to pay "7 percent of [their] net disability check, which was [their] only source of income," to their LFOs (p. 64), illustrating the cycle of the housing instability-LFO nexus among the poor. Hence the concept of microlevel FDD captures the ways in which the criminal legal system maintains these social and economic inequalities by assessing LFOs on those who are economically fragile and receiving public assistance as their primary source of income.

Similarly, April Fernandes, Brittany Friedman, and Gabriela Kirk (2022) argue that the state's arguments to recoup costs are imbued with legal moralism, which advocates that the law act as arbiter of morality. Considering the broader capitalist economic system and the state's use of legal moralism, value and performance are tied to fiscal responsibility. Therefore, anyone using state resources (those incarcerated, people on public assistance, and so on) are considered morally reprehensible and a drain on the state. In this way, incarceration and involvement in the larger criminal justice apparatus becomes a fiscal burden created and sustained by those who are affected by the system. "Willful nonpayment" is used in pay-tostay lawsuits because "incarcerated people with any modicum of assets then become willful nonpayers" (p. 89). The possession of assets in any form, including receipt of public assistance, can then be used to substantiate willful nonpayment of monetary sanctions. By framing the use of state resources as a moral failing, and the retention of any assets as willful nonpayment, the state not only justifies lawsuits to recoup costs from incarcerated persons, but also engages in macro-level FDD by imposing and collecting monetary sanctions from people receiving public assistance, only to redistribute those safety net resources to the criminal legal system and other state institutions.

Second, significant policy implications follow from FDDs. Colloquially referred to as the "anti-attachment statute," Section 207 of the Social Security Act (42 USC §407) prevents Social Security benefits from being garnished, levied, or withheld by the federal government. Specifically, the statute makes clear that "none of the moneys paid or payable or rights existing under this subchapter shall be subject to execution, levy, attachment, garnishment, or other legal process, or to the operation of any bankruptcy or insolvency law" (42 USC §407(a), emphasis added). A few exceptions to this antiattachment statute bear mention: child support and alimony obligations (42 USC $§ 659$ ); certain civil penalties under the Mandatory Victim Restitution Act (18 USC§3613); overdue federal taxes (26 USC §6334; Public Law 105-34); or withholding and paying another federal agency a nontax debt owed according to the Debt Collection Improvement Act of 1996 (Public Law 104-134). In other words, with only a few exceptions, the purpose of the statute is to protect a minimum standard of living for individuals with low income or disabilities by safeguarding Social Security benefits from paying other debt.

The anti-attachment statute for Social Security benefits has been used to prevent FDDs in at least one state in the United States. In State of Washington v. Catling, 193 Wn.2d 252, 438 3d 1174 (2019), the court held that LFOs "may not be satisfied out of any funds subject to the Social Security Act's anti-attachment statute, 42 USC§407" (266). Although the defendant in this 
case was required to pay the $\$ 500$ victim fund assessment as dictated by Section 207 of the Social Security Act (42 USC §407) (Section 207), the court held that such debt could not be settled with Social Security disability benefits. A series of recently filed cases raise similar issues in Washington since the State of Washington $v$. Catling ruling. All citing Catling, the courts conclude that although the imposition of fines and fees are legal, the judgment and sentences must be amended to specify that the mandatory LFOs may not be satisfied out of funds subject to the anti-attachment statute. ${ }^{3}$

Additionally, in a cursory review of recent case law, two lawsuits-one decided by the Montana Supreme Court and another in the Missouri Supreme Court-question the definition of "other legal process" in Section 207. In State of Montana v. Ingram, 2020 Mt. 327, the Supreme Court of Montana ruled that the District Court's sentencing order-in which it imposed the statutory minimum fine of $\$ 5,000$ for felony driving under the influence (DUI) - constitutes an "other legal process" and thus an improper attempt was made to attach the appellant's Social Security benefits-which was Ingram's sole source of income, \$857 per month-in violation of 42 USC $\S 407(a)$. Although the court ruled in Ingram's favor, in its decision it makes clear that, just as was held in State v. Catling, 193 Wn.2d 252, 438 3d 1174 (2019), Ingram's receipt of Social Security benefits does not exempt him from having to pay the mandatory fine. Instead, it prohibits the attachment of those benefits to pay off the fine.

In a second case, argued before the Supreme Court of Missouri on October 6, 2020, a similar question was raised as to whether payment of a monthly intervention fee as a condition of probation violates federal law by subjecting $\mathrm{Mr}$. Graves' supplemental Social Security benefits to "other legal process," (Graves v. Missouri Department of Corrections, Mo. Ct. App. Mar. 31, 2020). In a 4-3 decision issued on October 5, 2021, the Missouri Supreme court decided that "Because the Division [of Probation and Parole] has not yet compelled Graves to pay monthly fees, his request for declaratory relief is not ripe for adjudication and the circuit court properly dismissed his claim," (Graves v. Missouri Department of Corrections, Mo: Supreme Court 2021). ${ }^{4}$

These recent court decisions in Montana and Missouri underscore the confusion surrounding Section 207 of the Social Security Act and its meaning in the context of LFOs. Based on decided court cases, it seems that misunderstandings about Section 207 are largely driven by the need for clarity surrounding legal exceptions to the provision, as well as a need for an operational definition of "other legal process." Although Section 207 protects financial resources from state extraction and FDD, in regard to Social Security benefits, our analysis reveals that similar laws and administrative policies are necessary to protect other forms of public benefits, cash and noncash alike, from being directly and indirectly redistributed from the social welfare to the penal hands of the state (on the payment of monetary sanctions using disability assistance, see Cadigan and Smith 2021). To do so, social policies must be carefully devised to consider whether specific types of public assistance receipt should be levied against the imposition and collection of LFOs. Noncash public assistance may pose a particular challenge for courts, as the loss of these benefits may require real economic expenditures by indigent individuals and their families. However, receipt of such noncash benefits in-and-of itself points to financial hardships that may well justify waived or expunged

3. State v. Stone, No. 52233-1-II (Wash. Ct. App. Feb. 19, 2020); State v. Dillon, 456 P.3d 1199, 12 Wn. App. 2 d 133 (Wash. Ct. App. 2020); and State v. Devine, No. 81098-7-I (Wash. Ct. App. Apr. 12, 2021).

4. It is important to note, however, that in their dissenting opinion, justices argued that, “The plain language of Mr. Graves' petition shows he sought a declaration that the division's imposition of an intervention fee of $\$ 30$ per month as a condition of his probation violated 42 U.S.C. section 407(a) because his only income was supplemental security income ("SSI"). When this claim is acknowledged and evaluated, the correct holding is that the petition pleads facts that state a claim for declaratory judgment" (Graves v. Missouri Department of Corrections, Mo: Supreme Court 2021). 
LFOs in criminal sentences. Therefore, policymakers should consider preventing the imposition and collection of monetary sanctions on all persons receiving any form of public assistance, especially those that are antipoverty or a means-tested public benefit.

\section{CONCLUSION}

The welfare reforms passed in the 1990s were an expression of the neoliberal logics of American public policy (Simon 2007; Hinton 2016; Wacquant 2009), through which the penal arm of the state became increasingly more powerful (Wacquant 2010). The efforts to dramatically tighten public assistance were framed as a way to hold individuals accountable and responsible for themselves and attend to what was perceived as the growing dependency on government resources (Edin and Lein 1997; Edin and Kefalas 2005; Edin et al. 2019; Edin and Nelson 2013; Gustafson 2012; Wilson 1987), which further marginalized people living in poverty. Our findings confirm this trend, in that individuals and families who receive public assistance are less likely to pay LFOs, even when the imposed LFOs are less than the amounts imposed on individuals and families who do not receive public assistance. Put simply, individuals and families at the highest risk of FDD are also at the highest risk of being further penalized for failing to pay LFOs. Even though people on public assistance may have lower monetary sanctions imposed, their poverty and economic hardships imply that they should not have these LFOs imposed at all, as their failure to pay even small amounts can trigger extended justice system involvement and surveillance. This finding is why some judges and probation officers rely on bench cards to assess indigence or public assistance receipt as a marker of poverty instead of relying on employment or income alone (see Harris, Pattillo, and Sykes 2022, this volume; Martin 2020).

Although we agree with Wacquant's (2010) theoretical framework, we find that the transfer of resources from the state's left to right hand (from social welfare to punishment) is a dynamic process that disproportionately harms individuals and families on public assistance who have criminal justice debt. Indeed, recent research on neoliberalism and punishment also calls into question the process that Wacquant theorizes (Lara-Millán 2021); interestingly, however, the process that Armando LaraMillán (2021, 42) describes-where poor individuals "game the system" by committing crimes in order to receive health care in local jails because of underfunding to, and overcrowding in, public hospitals-speaks to the very mechanism of FDD at the micro and macro levels, as state resources allocated to one institution can diffuse downward through individuals and be redistributed to other state agencies. The only difference in this case of FDD, however, is that the liabilities are passed from one institution to another via individuals, as opposed to assets or resources derived from social safety net provisions, including Medicare. ${ }^{5}$

The neoliberal shift to decrease social safety net funding and to increase fiscal allocations for punishment and surveillance is not new. Families experiencing poverty have historically been affected by the underfunding of public assistance programs and the growing punitiveness of the criminal legal system. The restructuring of the child-support system in the 1970s mandated families receiving public benefits (cash welfare) participate in surveillance systems that impose the collection of financial resources from noncustodial parents (Cozzolino 2018; Farrell, Glosser, and Gardiner 2003; Turetsky and Waller 2020), and these child-support enforcement and collection methods have since been applied to the collection of monetary sanctions (Legler 1996). Although child-support programs have demanded large payments from fathers unable to meet these obligations (Ha, Cancian, and Meyer 2018; Sorensen and Oliver 2002), similar to criminal justice debt, child-support collections have been shown to intensify family

\footnotetext{
5. Josh Seim $(2020,6)$ also argues that, during an era of increasing economic and social precarity, "the neoliberal shift toward market-based policies" has led to a "'medicalization' of public aid, meaning people are turning to medical entitlements like public disability benefits and emergency care for more generalized assistance," resulting in increased ambulance usage as healthcare instead of routine primary care.
} 
hardship and erode family ties (Bartfeld 2003; Turner and Waller 2017; on criminal justice debt and family relations, see Boches et al. 2022, this volume). Within this context, the left and right hands of the state were always embedded in poverty management and the ascension of the punitive apparatus.

In short, contemporary research on poverty, inequality, and monetary sanctions misses a key dimension of predatory extraction: public assistance and social safety net resources. This omission is deeply consequential for the measurement of poverty and poverty mitigation (see also Fox et al. 2015), as judicial decisions about the imposition of monetary sanctions often consider resources associated with public assistance programs. Implications derived from our findings suggest that state fiscal budgets, and their reallocations and redistribu- tions over time, paint a partial picture of the resources circulating to and through the criminal legal system. To capture more fully the totality of resources appropriated by the punishment sphere of the state through financial double-dealing, research needs to qualify and quantify the micro-level and macro-level redistribution of money from individuals and families receiving public assistance while paying down monetary sanctions. Policymakers and advocates also need to devise and enact new legislation that safeguards precious social safety net resources from being funneled back into the criminal legal system via monetary sanctions. Failure to do so will undoubtedly deepen the poverty, hardship, and misery of millions of individuals and families experiencing economic precarity in an age of growing social inequality.

Table A1. Log-Odds of Having Any Public Assistance Associated with Criminal Justice Debt

\begin{tabular}{|c|c|c|c|}
\hline & (1) & (2) & (3) \\
\hline \multirow[t]{2}{*}{ Any Public Assistance } & $0.415^{* * *}$ & $0.150 *$ & $0.579 * * *$ \\
\hline & $(0.0608)$ & $(0.0683)$ & $(0.152)$ \\
\hline \multirow[t]{2}{*}{ Violent Crime Victim } & & $0.794^{* * *}$ & $0.589 * * *$ \\
\hline & & $(0.106)$ & $(0.106)$ \\
\hline \multirow[t]{2}{*}{ Previous Incarceration } & & $2.371^{* * *}$ & $2.209 * * *$ \\
\hline & & (0.118) & $(0.114)$ \\
\hline \multirow[t]{2}{*}{ Age } & & & $-0.0285^{* * *}$ \\
\hline & & & $(0.00421)$ \\
\hline \multirow[t]{2}{*}{ Non-Hispanic Black } & & & $0.372^{* *}$ \\
\hline & & & $(0.137)$ \\
\hline \multirow[t]{2}{*}{ Hispanic } & & & 0.200 \\
\hline & & & $(0.184)$ \\
\hline \multirow[t]{2}{*}{ Non-Hispanic Other } & & & -0.0230 \\
\hline & & & $(0.281)$ \\
\hline \multirow[t]{2}{*}{ Non-Hisp. Multiracial } & & & $0.455^{* *}$ \\
\hline & & & $(0.170)$ \\
\hline \multirow[t]{2}{*}{ Female } & & & $0.218^{* *}$ \\
\hline & & & $(0.0844)$ \\
\hline \multirow[t]{2}{*}{ Single } & & & -0.108 \\
\hline & & & $(0.116)$ \\
\hline \multirow[t]{2}{*}{ Cohabiting } & & & 0.171 \\
\hline & & & $(0.136)$ \\
\hline \multirow[t]{2}{*}{ Separated/Divorced } & & & $0.423^{* *}$ \\
\hline & & & $(0.141)$ \\
\hline \multirow[t]{2}{*}{ Widowed } & & & 0.258 \\
\hline & & & $(0.239)$ \\
\hline \multirow[t]{2}{*}{ Household Size } & & & $0.0728^{*}$ \\
\hline & & & $(0.0321)$ \\
\hline
\end{tabular}


Table A1. (continued)

(1) (2) (3)

High School Diploma

$-0.185$

(0.191)

Some College or More

$-0.318^{+}$

Unemployed

(0.175)

Unemployed

$-0.333^{*}$

Income: $\$ 20,000-\$ 29,999$

(0.136)

Income: $\$ 20,000-\$ 29,999$

$-0.102$

Income: \$30,000-\$39,999

(0.166)

Income: $\$ 40,000-\$ 49,999$

$-0.211$

(0.163)

$-0.445^{*}$

(0.186)

Income: \$50,000-\$59,999

$-0.375$

(0.249)

Income: $\$ 60,000-\$ 74,999$

$-0.180$

Income: $\$ 75,000-\$ 84,999$

(0.194)

Income: \$85,000-\$99,999

$-0.400^{+}$

(0.241)

Income: $>=\$ 100,000$

(0.263)

$-0.501^{*}$

Metro

(0.209)

0.125

(0.147)

Mid-Atlantic

$1.197^{* * *}$

(0.0926)

East-North Central

$1.426 * * *$

(0.0920)

West-North Central

$0.663^{* * *}$

(0.0595)

South-Atlantic

$0.900^{* * *}$

East-South Central

(0.0794)

$1.034^{* * *}$

West-South Central

(0.118)

West-South Central

$0.936 * * *$

(0.0798)

Mountain

0.134

(0.0997)

Pacific

0.496 ***

(0.137)

Constant

$$
\begin{gathered}
-4.271^{* * *} \\
(0.0389)
\end{gathered}
$$

$-5.350 * * *$

$-3.811^{* * *}$

(0.0860)

(0.323)

Observations

12,014

12,014

12,014

Source: Authors' tabulation based on 2019 SHED data (Federal Reserve 2020).

Note: Non-Hispanic Whites, married, less than a high school education, household income below $\$ 20,000$, and New England region are the reference categories. All models include state fixed effects, and standard errors are clustered on state.

${ }^{* * *} p<.001,{ }^{* *} p<.01,{ }^{*} p<.05,{ }^{+} p<.10$ 
172 STATE MONETARY SANCTIONS AND THE COSTS OF THE CRIMINAL LEGAL SYSTEM

Table A2. Log-Odds of Having Cash and Non-Cash Public Assistance Associated with Criminal Justice Debt

\begin{tabular}{|c|c|c|c|c|c|c|}
\hline & \multicolumn{3}{|c|}{ Cash Support } & \multicolumn{3}{|c|}{ Non-Cash Support } \\
\hline & (1) & (2) & (3) & (4) & (5) & (6) \\
\hline \multirow[t]{2}{*}{ Any Public Assistance } & $-0.161^{* *}$ & $-0.331^{* * *}$ & $0.255^{*}$ & $1.572^{* * *}$ & $1.062^{* * *}$ & $0.688^{* * *}$ \\
\hline & $(0.0586)$ & $(0.0673)$ & $(0.112)$ & (0.0718) & $(0.0867)$ & $(0.142)$ \\
\hline \multirow[t]{2}{*}{ Violent Crime Victim } & & $0.815^{* * *}$ & $0.627^{* * *}$ & & $0.607^{* * *}$ & $0.559 * * *$ \\
\hline & & $(0.105)$ & (0.103) & & (0.108) & $(0.106)$ \\
\hline \multirow[t]{2}{*}{ Previous Incarceration } & & $2.407^{* * *}$ & $2.232^{* * *}$ & & $2.265^{* * *}$ & $2.210^{* * *}$ \\
\hline & & $(0.113)$ & $(0.111)$ & & $(0.119)$ & $(0.112)$ \\
\hline \multirow[t]{2}{*}{ Age } & & & $-0.0256^{* * *}$ & & & $-0.0193^{* * *}$ \\
\hline & & & $(0.00396)$ & & & $(0.00331)$ \\
\hline \multirow[t]{2}{*}{ Non-Hispanic Black } & & & $0.401^{* *}$ & & & $0.330^{*}$ \\
\hline & & & (0.138) & & & $(0.139)$ \\
\hline \multirow[t]{2}{*}{ Hispanic } & & & 0.205 & & & 0.178 \\
\hline & & & $(0.185)$ & & & (0.179) \\
\hline \multirow[t]{2}{*}{ Non-Hispanic Other } & & & -0.0385 & & & -0.0585 \\
\hline & & & $(0.277)$ & & & $(0.279)$ \\
\hline \multirow[t]{2}{*}{ Non-Hisp. Multiracial } & & & $0.457^{* *}$ & & & $0.444^{*}$ \\
\hline & & & $(0.166)$ & & & $(0.173)$ \\
\hline \multirow[t]{2}{*}{ Female } & & & $0.230^{* *}$ & & & $0.212^{*}$ \\
\hline & & & $(0.0844)$ & & & $(0.0850)$ \\
\hline \multirow[t]{2}{*}{ Single } & & & -0.144 & & & -0.100 \\
\hline & & & $(0.114)$ & & & $(0.113)$ \\
\hline \multirow[t]{2}{*}{ Cohabiting } & & & 0.189 & & & 0.171 \\
\hline & & & $(0.130)$ & & & $(0.137)$ \\
\hline \multirow[t]{2}{*}{ Separated/Divorced } & & & $0.386^{* *}$ & & & $0.344^{*}$ \\
\hline & & & $(0.142)$ & & & $(0.139)$ \\
\hline \multirow[t]{2}{*}{ Widowed } & & & 0.229 & & & 0.252 \\
\hline & & & $(0.243)$ & & & $(0.245)$ \\
\hline \multirow[t]{2}{*}{ Household Size } & & & $0.0901^{* *}$ & & & $0.0652^{*}$ \\
\hline & & & $(0.0326)$ & & & $(0.0327)$ \\
\hline \multirow[t]{2}{*}{ High School Diploma } & & & -0.185 & & & -0.125 \\
\hline & & & $(0.190)$ & & & $(0.189)$ \\
\hline \multirow[t]{2}{*}{ Some College or More } & & & $-0.340^{+}$ & & & -0.251 \\
\hline & & & $(0.177)$ & & & $(0.170)$ \\
\hline \multirow[t]{2}{*}{ Unemployed } & & & $-0.264^{*}$ & & & $-0.262^{*}$ \\
\hline & & & $(0.128)$ & & & $(0.127)$ \\
\hline \multirow[t]{2}{*}{ Income: $\$ 20,000-\$ 29,999$} & & & -0.127 & & & -0.0310 \\
\hline & & & $(0.163)$ & & & $(0.166)$ \\
\hline \multirow[t]{2}{*}{ Income: $\$ 30,000-\$ 39,999$} & & & $-0.288^{+}$ & & & -0.0855 \\
\hline & & & $(0.156)$ & & & $(0.170)$ \\
\hline \multirow[t]{2}{*}{ Income: $\$ 40,000-\$ 49,999$} & & & $-0.531^{* *}$ & & & $-0.334^{+}$ \\
\hline & & & $(0.187)$ & & & $(0.195)$ \\
\hline Income: $\$ 50,000-\$ 59,999$ & & & $-0.502^{*}$ & & & -0.254 \\
\hline & & & $(0.240)$ & & & $(0.263)$ \\
\hline Income: $\$ 60,000-\$ 74,999$ & & & $-0.324^{+}$ & & & -0.0670 \\
\hline & & & $(0.177)$ & & & $(0.196)$ \\
\hline Income: $\$ 75,000-\$ 84,999$ & & & $-0.560^{*}$ & & & -0.260 \\
\hline & & & $(0.219)$ & & & $(0.243)$ \\
\hline
\end{tabular}


Table A2. (continued)

\begin{tabular}{|c|c|c|c|c|c|c|}
\hline & \multicolumn{3}{|c|}{ Cash Support } & \multicolumn{3}{|c|}{ Non-Cash Support } \\
\hline & (1) & (2) & (3) & (4) & (5) & (6) \\
\hline \multirow[t]{2}{*}{ Income: $\$ 85,000-\$ 99,999$} & & & $-0.422^{+}$ & & & -0.143 \\
\hline & & & $(0.231)$ & & & $(0.256)$ \\
\hline \multirow[t]{2}{*}{ Income: >=\$100,000 } & & & $-0.683^{* * *}$ & & & $-0.386^{+}$ \\
\hline & & & $(0.174)$ & & & $(0.214)$ \\
\hline \multirow[t]{2}{*}{ Metro } & & & 0.0996 & & & 0.112 \\
\hline & & & $(0.143)$ & & & $(0.148)$ \\
\hline \multirow[t]{2}{*}{ Mid-Atlantic } & & & $1.259^{* * *}$ & & & $1.301^{* * *}$ \\
\hline & & & $(0.0718)$ & & & $(0.0751)$ \\
\hline \multirow[t]{2}{*}{ East-North Central } & & & $1.484^{* * *}$ & & & $1.528^{* * *}$ \\
\hline & & & $(0.0747)$ & & & $(0.0782)$ \\
\hline \multirow[t]{2}{*}{ West-North Central } & & & $0.651^{* * *}$ & & & $0.793^{* * *}$ \\
\hline & & & $(0.0552)$ & & & $(0.0568)$ \\
\hline \multirow[t]{2}{*}{ South-Atlantic } & & & $0.956^{* * *}$ & & & $1.018^{* * *}$ \\
\hline & & & $(0.0653)$ & & & $(0.0689)$ \\
\hline \multirow[t]{2}{*}{ East-South Central } & & & $1.093^{* * *}$ & & & $1.160^{* * *}$ \\
\hline & & & $(0.112)$ & & & $(0.114)$ \\
\hline \multirow[t]{2}{*}{ West-South Central } & & & $0.984^{* * *}$ & & & $1.050^{* * *}$ \\
\hline & & & (0.0804) & & & $(0.0786)$ \\
\hline \multirow[t]{2}{*}{ Mountain } & & & $0.194^{*}$ & & & $0.207^{*}$ \\
\hline & & & (0.0955) & & & $(0.0991)$ \\
\hline \multirow[t]{2}{*}{ Pacific } & & & $0.641^{* * *}$ & & & $0.525^{* * *}$ \\
\hline & & & $(0.122)$ & & & $(0.145)$ \\
\hline \multirow[t]{2}{*}{ Constant } & $-3.946^{* * *}$ & $-5.180^{* * *}$ & $-3.753^{* * *}$ & $-4.351^{* * *}$ & $-5.513^{* * *}$ & $-4.337^{* * *}$ \\
\hline & $(0.0275)$ & $(0.101)$ & $(0.330)$ & $(0.0244)$ & $(0.0968)$ & $(0.300)$ \\
\hline Observations & 12,014 & 12,014 & 12,014 & 12,014 & 12,014 & 12,014 \\
\hline
\end{tabular}

Source: Authors' tabulation based on 2019 SHED data (Federal Reserve 2020).

Note: Non-Hispanic Whites, married, less than a high school education, household income below $\$ 20,000$, and New England region are the reference categories. All models include state fixed effects, and standard errors are clustered on state.

${ }^{* * *} p<.001,{ }^{* *} p<.01,{ }^{*} p<.05,{ }^{+} p<.10$ 


\section{REFERENCES}

Adamson, Christopher R. 1983. “Punishment After Slavery: Southern State Penal Systems, 18651890." Social Problems 30(5): 555-69.

Alexander, Michelle. 2010. The New Jim Crow: Mass Incarceration in the Age of Colorblindness. New York: The New Press.

Anderson, Helen A. 2008. “Penalizing Poverty: Making Criminal Defendants Pay for Their CourtAppointed Counsel Through Recoupment and Contribution." University of Michigan Journal of Law Reform 42(2): 323-80.

Bannon, Alicia, Mitali Nagrecha, and Rebekah Diller. 2010. Criminal Justice Debt: A Barrier to Reentry. New York: Brennan Center for Justice.

Bartfeld, Judi. 2003. “Falling Through the Cracks: Gaps in Child Support Among Welfare Recipients." Journal of Marriage and Family 65(1): 7289.

Bayot, Jennifer. 2004. "Use of Credit Records Grows in Screening of Job Applicants." New York Times, March 28, A10.

Becker, Gary. 1968. “Crime and Punishment: An Economic Approach." Journal of Political Economy, 76(2): 169-217.

- 1976. The Economic Approach to Human Behavior. Chicago: University of Chicago Press.

Beckett, Katherine, and Alexes Harris. 2011. “On Cash and Conviction: Monetary Sanctions as Misguided Policy." Criminology \& Public Policy 10(3): 505-7.

Beckett, Katherine, and Naomi Murakawa. 2012. “Mapping the Shadow Carceral State: Toward an Institutionally Capacious Approach to Punishment." Theoretical Criminology 16(2): 221-44.

Beckett, Katherine, and Bruce Western. 2001. “Governing Social Marginality: Welfare, Incarceration, and the Transformation of State Policy." Punishment \& Society 3(1): 43-59.

Bing, Leslie, Becky Pettit, and Ilya Slavinski. 2022. “Incomparable Punishments: How Economic Inequality Contributes to the Disparate Impact of Legal Fines and Fees." RSF: The Russell Sage Foundation Journal of the Social Sciences 8(1): 118-36. DOI: https://doi.org/10.7758/RSF.2022 8.1.06.

Blackmon, Douglas A. 2009. Slavery by Another Name: The Re-Enslavement of Black Americans from the Civil War to World War II. New York: Anchor Books.

Boches, Daniel J., Brittany T. Martin, Andrea Giuffre,
Amairini Sanchez, Aubrianne L. Sutherland, and Sarah K.S. Shannon. 2022. “Monetary Sanctions and Symbiotic Harms." RSF: The Russell Sage Foundation Journal of the Social Sciences 8(2): 98-115. DOI: https://doi.org/10.7758/RSF.2022 8.2.05.

Bourdieu, Pierre. 1994. "Rethinking the State: Genesis and Structure of the Bureaucratic Field." Sociological Theory 12(1): 1-18.

Bradley, Jana. 1993. "Methodological Issues and Practices in Qualitative Research." The Library Quarterly 63(4): 431-449.

Brayne, Sarah. 2014. "Surveillance and System Avoidance: Criminal Justice Contact and Institutional Attachment." American Sociological Review 79(3): 367-91.

Cadigan, Michele, and Tyler Smith. 2021. "'Are You Able-Bodied?' Embodying Accountability in the Modern Criminal Justice System." Journal of Contemporary Criminal Justice 37(1): 25-44.

Chetty, Raj, Nathaniel Hendren, Patrick Kline, Emmanuel Saez, and Nicholas Turner. 2014. "Is the United States Still a Land of Opportunity? Recent Trends in Intergenerational Mobility." American Economic Review 104 (5): 141-47.

Colgan, Beth A. 2014. "Paying for Gideon." lowa Law Review 99(5): 1929-49.

Conger, Jay A. 1998. “Qualitative Research as the Cornerstone Methodology for Understanding Leadership." Leadership Quarterly 9(1): 107-21.

Cozzolino, Elizabeth. 2018. "Public Assistance, Relationship Context, and Jail for Child Support Debt." Socius 4(1): 1-25.

Edin, Kathryn, and Maria Kefelas. 2005. Promises I Can Keep: Why Poor Women Put Motherhood Before Marriage. Berkeley: University of California Press.

Edin, Kathryn, and Laura Lein. 1997. Making Ends Meet: How Single Mothers Survive Welfare and Low-Wage Work. New York: Russell Sage Foundation.

Edin, Kathryn, and Timothy J. Nelson. 2013. Doing the Best I Can: Fatherhood in the Inner City. Berkeley: University of California Press.

Edin, Kathryn, Timothy J. Nelson, Rachel Butler, and Robert Francis. 2019. “Taking Care of Mine: Can Child Support Become a Family-Building Institution?" Journal of Family Theory \& Review 11(1): 79-91.

Farrell, Mary, Asaph Glosser, and Karen Gardiner. 2003. "Child Support and TANF Interaction: Lit- 
erature Review." Prepared for Assistant Secretary for Planning and Evaluation. New York: Manpower Demonstration Research Corporation.

Federal Reserve. 2020. "Report on the Economic Well-Being of U.S. Households in 2019, Featuring Supplemental Data from April 2020." Washington: Federal Reserve Board. Accessed August 12, 2021. https://www.federalreserve.gov /publications/files/2019-report-economic-well -being-us-households-202005.pdf.

Fernandes, April D., Michele Cadigan, Frank Edwards, and Alexes Harris. 2019. “Monetary Sanctions: A Review of Revenue Generation, Legal Challenges, and Reform." Annual Review of Law and Social Science 15(1): 397-413.

Fernandes, April D., Brittany Friedman, and Gabriela Kirk. 2022. "The 'Damaged' State vs. the 'Willful' Nonpayer: Constructing Damager, Harm, and Willfulness Through Pay-to-Stay Lawsuits." RSF: The Russell Sage Foundation Journal of the Social Sciences 8(1): 82-105. DOI: https://doi.org/10 .7758/RSF.2022.8.1.04.

Foster, Holly, and John Hagan. 2007. "Incarceration and Intergenerational Social Exclusion." Social Problems 54(4): 399-433.

Fox, Liana, Brian Glassman, and Jose Pacas. 2020. "The Supplemental Poverty Measure Using the American Community Survey." SEHSD working paper 2020-09. Washington: U.S. Census Bureau. Accessed August 10, 2021. https://www .census.gov/content/dam/Census/library /working-papers/2020/demo/SEHSD-WP2020 -09.pdf.

Fox, Liana, Christopher Wimer, Irwin Garfinkel, Neeraj Kaushal, JaeHyun Nam, and Jane Waldfogel. 2015. “Trends in Deep Poverty from 1968 to 2011: The Influence of Family Structure, Employment Patterns, and the Safety Net." RSF: The Russell Sage Foundation Journal of the Social Sciences 1(1): 14-34. DOI: https://doi.org/10.7758 /RSF.2015.1.1.02.

Friedman, Brittany, Alexes Harris, Beth M. Huebner Karin D. Martin, Becky Pettit, Sarah K.S. Shannon, and Bryan L. Sykes. 2022. "What Is Wrong with Monetary Sanctions? Directions for Policy, Practice, and Research." RSF: The Russell Sage Foundation Journal of the Social Sciences 8(1): 221-43. DOI: https://doi.org/10.7758/RSF.2022 8.1.10.

Friedman, Brittany, and Mary Pattillo. 2019. "Statutory Inequality: The Logics of Monetary Sanc- tions in State Law." RSF: The Russell Sage Foundation Journal of the Social Sciences 5(1): 174-96. DOI: https://doi.org/10.7758/RSF.2019.5.1.08.

Gordon, Margaret A., and Daniel Glaser. 1991. "The Use and Effects of Financial Penalties in Municipal Courts." Criminology 29(4): 651-76.

Gustafson, Kaaryn S. 2012. Cheating Welfare: Public Assistance and the Criminalization of Poverty. New York: New York University Press.

Ha, Yoonsook, Maria Cancian, and Daniel R. Meyer. 2018. "Child Support and Income Inequality." Poverty \& Public Policy 10(2): 147-58.

Hagan, John, Holly Foster, and Chantrey J. Murphy. 2020. "A Tale Half Told: State Exclusionary and Inclusionary Regimes, Incarceration of Fathers, and the Educational Attainment of Children." Social Science Research 88-89 (May-July).

Haney, Lynne. 2018. “Incarcerated Fatherhood: The Entanglements of Child Support Debt and Mass Imprisonment." American Journal of Sociology 124(1): 1-48.

Harris, Alexes. 2016. A Pound of Flesh: Monetary Sanctions as Punishment for the Poor. New York: Russell Sage Foundation.

Harris, Alexes, Heather Evans, and Katherine Beckett. 2010. “Drawing Blood from Stones: Legal Debt and Social Inequality in the Contemporary United States." American Journal of Sociology 115(6): 1753-99.

Harris, Alexes, Beth M. Huebner, Karin D. Martin, Mary Pattillo, Becky Pettit, Sarah K.S. Shannon, Bryan L. Sykes, and Christopher Uggen. 2018. “United States Systems of Justice, Poverty and the Consequences of Non-Payment of Monetary Sanctions: Interviews from California, Georgia, IIlinois, Minnesota, Missouri, Texas, New York, and Washington." Multi-State Study Report no. 2. Houston, Tex.: Laura and John Arnold Foundation. Accessed July 23, 2021. http://www .monetarysanctions.org/wp-content/uploads /2018/01/Monetary-Sanctions-2nd-Year-Report .pdf.

Harris, Alexes, Mary Pattillo, and Bryan L. Sykes. 2022. "Studying the System of Monetary Sanctions." RSF: The Russell Sage Foundation Journal of the Social Sciences 8(1): 1-33. DOI: https://doi. org/10.7758/RSF.2022.8.1.01.

Hinton, Elizabeth. 2016. From the War on Poverty to the War on Crime: The Making of Mass Incarceration in America. Cambridge, Mass.: Harvard University Press. 
Huebner, Beth M., and Sarah K.S. Shannon. 2022.

"Private Probation Costs, Compliance, and the Proportionality of Punishment: Evidence from Georgia and Missouri." RSF: The Russell Sage Foundation Journal of the Social Sciences 8(1): 179-99. DOI: https://doi.org/10.7758/RSF.2022 8.1.08.

Ingraham, Christopher. 2020. “U.S. Spends Twice as Much on Law and Order as It Does on Cash Welfare, Data Show." Washington Post, June 4. Accessed July 20, 2021. https://www .washingtonpost.com/business/2020/06/04/us -spends-twice-much-law-order-it-does-social -welfare-data-show.

Kirk, Gabriela, April D. Fernandes, and Brittany Friedman. 2020. “Who Pays for the Welfare State? Austerity Politics and the Origin of Payto-Stay Fees as Revenue Generation." Sociological Perspectives 63(6): 921-38.

Kohler-Hausmann, Issa. 2018. Misdemeanorland: Criminal Courts and Social Control in an Age of Broken Windows Policing. Princeton, N.J.: Princeton University Press.

Lara-Millán, Armando. 2021. Redistributing the Poor: Jails, Hospitals, and the Crisis of Law and Fiscal Austerity. New York: Oxford University Press.

Legler, Paul K. 1996. “The Coming Revolution in Child Support Policy: Implications of the 1996 Welfare Act." Family Law Quarterly 30(3): 51963.

Lundberg, Ian, and Louis Donnelly. 2019. “A Research Note on the Prevalence of Housing Eviction Among Children Born in U.S. Cities." Demography 56(1): 391-404.

MacLeod, Jay. 2009. Ain't No Makin' It: Aspirations and Attainment in a Low-Income Neighborhood, 3rd ed. Boulder, Colo.: Westview Press.

Margo, Robert. 1993. "Employment and Unemployment in the 1930s." Journal of Economic Perspectives 7(2): 41-59.

Maroto, Michelle Lee. 2015. “The Absorbing Status of Incarceration and Its Relationship with Wealth Accumulation." Journal of Quantitative Criminology 31(2): 207-36.

Maroto, Michelle, and Bryan L. Sykes. 2020. “The Varying Effects of Incarceration, Conviction, and Arrest on Wealth Outcomes Among Young Adults." Social Problems 67(4): 698-718.

Martin, Karin D. 2020. "'The Plurality of Perspectives on Monetary Sanctions': An Introductory Essay." Sociological Perspectives 63(6): 901-20.
Martin, Karin D., Bryan L. Sykes, Sarah K.S. Shannon, Frank Edwards, and Alexes Harris. 2018. "Monetary Sanctions: Legal Financial Obligations in US Systems of Justice." Annual Review of Criminology 1(1): 471-95.

Mayring, Philipp. 2001. "Combination and Integration of Qualitative and Quantitative Analysis." Forum, Qualitative Social Research 2(1): 1-21.

Miles, Matthew B., and A. M. Huberman. 1994. Qualitative Data Analysis: An Expanded Sourcebook, 2nd ed. Thousand Oaks: Sage Publications.

Muñiz, Ana. 2020. “Secondary Ensnarement: Surveillance Systems in the Service of Punitive Immigration Enforcement." Punishment \& Society 22(4): 461-82.

National Research Council. 2014. The Growth of Incarceration in the United States: Exploring Causes and Consequences, edited by Jeremy Travis, Bruce Western, and Steve Redburn for the National Research Council. Washington, DC: National Academies Press.

O'Malley, Pat. 2009. “Theorizing Fines." Punishment and Society 11(1): 67-83.

O'Neill, Kate K., Tyler Smith, and Ian Kennedy. 2022. "County Dependence on Monetary Sanctions: Implications for Women's Incarceration." RSF: The Russell Sage Foundation Journal of the Social Sciences 8(2): 157-72. DOI: https://doi.org/10 .7758/RSF.2022.8.1.08.

Page, Joshua, Victoria Piehowski, and Joe Soss. 2019. "A Debt of Care: Commercial Bail and the Gendered Logic of Criminal Justice Predation." RSF: The Russell Sage Foundation Journal of the Social Sciences 5(1): 150-72. DOI: https://doi .org/10.7758/RSF.2019.5.1.07.

Pager, Devah. 2003. "The Mark of a Criminal Record." American Journal of Sociology 108(5): 93775.

Pager, Devah, Bart Bonikowski, and Bruce Western. 2009. "Discrimination in a Low-Wage Labor Market: A Field Experiment." American Sociological Review 74(5): 777-99.

Pager, Devah, and Lincoln Quillian. 2005. “Walking the Talk? What Employers Say Versus What They Do." American Sociological Review 70(3): 355-80.

Pattillo, Mary, Erica Banks, Brian Sargent, and Daniel J. Boches. 2022. “Monetary Sanctions and Housing Instability." RSF: The Russell Sage Foundation Journal of the Social Sciences 8(2): 57-75. DOI: https://doi.org/10.7758/RSF.2022.8.1.03. 
Pattillo, Mary, and Gabriela Kirk. 2020. “Pay Unto Caesar: Breaches of Justice in the Monetary Sanctions Regime." UCLA Criminal Justice Law Review 4(1): 49-77.

_. 2021. "Layaway Freedom: Coercive Financialization in the Criminal Legal System." American Journal of Sociology 126(4): 889-930.

Pettit, Becky. 2012. Invisible Men: Mass Incarceration and the Myth of Black Progress. New York: Russell Sage Foundation.

Pettit, Becky, and Christopher J. Lyons. 2009. “Incarceration and the Legitimate Labor Market: Examining Age-Graded Effects on Employment and Wages." Law \& Society Review 43(4): 725-56.

Pimpare, Stephen. “Great Recession vs. Great Depression." 2014. In The New Faces of American Poverty: A Reference Guide to the Great Recession, edited by Lindsey K. Hanson and Timothy J. Essenburg. Santa Barbara, Calif.: ABC-CLIO.

Pleggenkuhle, Breanne. 2018. “The Financial Cost of a Criminal Conviction: Context and Consequences." Criminal Justice and Behavior 45(1): 121-45.

Rauschway, Eric. 2008. The Great Depression and the New Deal: A Very Short Introduction. New York: Oxford University Press.

Ruback, R. Barry, Jennifer N. Shaffer, and Melissa A. Logue. 2004. “The Imposition and Effects of Restitution in Four Pennsylvania Counties: Effects of Size of County and Specialized Collection Units." Crime and Delinquency 50(2): 16888.

Saez, Emmanuel, and Gabriel Zucman. 2019. The Triumph of Injustice: How the Rich Dodge Taxes and How to Make Them Pay. New York: W. W. Norton.

Schilling, Jan. 2006. “On the Pragmatics of Qualitative Assessment: Designing the Process for Content Analysis." European Journal of Psychological Assessment 22(1): 28-37.

Schwartz-Soicher, Ofira, Amanda Geller, and Irwin Garfinkel. 2011. "The Effect of Paternal Incarceration on Material Hardship." Social Service Review 85(3): 447-73.

Semega, Jessica, Melissa Kollar, Emily A. Shrider, and John Creamer. 2020. "Income and Poverty in the United States: 2019." CRS report no. P60270. Washington: U.S. Census Bureau.

Siem, Josh. 2020. Bandage, Sort, and Hustle: Ambulance Crews on the Front Lines of Urban Suffering. Oakland: University of California Press.
Simon, Jonathan. 2007. Governing Through Crime: How the War on Crime Transformed American Democracy and Created a Culture of Fear. New York: Oxford University Press.

Smolensky, Eugene, and Robert Plotnick. 1993. "Inequality and Poverty in the United States: 1900 to 1990." Institute for Research on Poverty discussion paper no. 998-93. Madison: University of Wisconsin. https://www.irp.wisc.edu /publications/dps/pdfs/dp99893.pdf.

Solomon-Fears, Carmen, Alison M. Smith, and Carla Berry. 2012. “Child Support Enforcement: Incarceration as the Last Resort Penalty for Nonpayment of Support." The Green Book.

Sorensen, Elaine, and Helen Oliver. 2002. “Policy Reforms Are Needed to Increase Child Support from Poor Fathers." Washington, DC: Urban Institute.

Srnka, Katharina J., and Sabine T. Koeszegi. 2007. “From Words to Numbers: How to Transform Qualitative Data into Meaningful Quantitative Results." Schmalenbach Business Review 59(1): 29-57.

Sugie, Naomi. 2012. "Punishment and Welfare: Paternal Incarceration and Families' Receipt of Public Assistance." Social Forces 90(4): 1403-27.

Sykes, Bryan L., and Michelle Maroto. 2016. “A Wealth of Inequalities: Mass Incarceration, Employment, and Racial Disparities in U.S. Household Wealth, 1996-2011." RSF: The Russell Sage Foundation Journal of the Social Sciences 2(6): 129-52. DOI: https://doi.org/10.7758/RSF.2016 2.6.07.

Sykes, Bryan L., and Becky Pettit. 2015. “Severe Deprivation and System Inclusion Among Children of Incarcerated Parents in the United States After the Great Recession." RSF: The Russell Sage Foundation Journal of the Social Sciences 1(2): 108-32. DOI: https://doi.org/10.7758/RSF.2015 1.2.06.

Turetsky, Vicki. 2005. "What If All the Money Came Home? Welfare Cost Recovery in the Child Support Program." Family Court Review 43(3): 40214.

Turetsky, Vicki, and Maureen R. Waller. 2020. “Piling on Debt: The Intersections Between Child Support Arrears and Legal Financial Obligations." UCLA Criminal Justice Law Review 4(1): 117-41.

Turner, Kimberly, and Maureen R. Waller. 2017. “Indebted Relationships: Child Support Arrears and Nonresident Fathers' Involvement with Chil- 
dren." Journal of Marriage and Family 79(1): 24-43.

Urban Institute. 2020. “Public Welfare Expenditures." State and Local Finance Initiative. Accessed August 10, 2021. https://www.urban.org /policy-centers/cross-center-initiatives/state-and -local-finance-initiative/state-and-local -backgrounders/public-welfare-expenditures.

U.S. Census Bureau (Census Bureau). 2015. “21.3 Percent of US Participates in Government Assistance Programs Each Month." Press Release no. CB15-97, May 28. Washington: U.S. Department of Commerce. Accessed August 10, 2021. https://www.census.gov/newsroom/archives /press-releases/2015-pr/cb15-97.html.

Verma, Anjuli C., and Bryan L. Sykes. 2022. “Beyond the Penal Code: The Legal Capacity of Monetary Sanctions in the Corpus of California Law." RSF: The Russell Sage Foundation Journal of the Social Sciences 8(1): 36-62. DOI: https://doi.org/10 .7758/RSF.2022.8.1.02.
Wacquant, Loïc. 2009. Punishing the Poor: The Neoliberal Government of Social Insecurity. Durham, N.C.: Duke University Press.

—. 2010. "Crafting the Neoliberal State: Workfare, Prisonfare, and Social Insecurity." Sociological Forum 25(2): 197-220.

Western, Bruce. 2018. Homeward: Life in the Year After Prison. New York: Russell Sage Foundation.

Western, Bruce, and Christopher Wildeman. 2009. "The Black Family and Mass Incarceration." The Annals of the American Academy of Political and Social Science 621: 221-42.

Wilson, William Julius. 1987. The Truly Disadvantaged: The Inner City, the Underclass, and Public Policy. Chicago: University of Chicago Press.

Wood, Erika L., and Neema Trivedi. 2007. “The Modern-Day Poll Tax: How Economic Sanctions Block Access to the Polls." Clearinghouse Review 41(1): 30-45. 